\title{
Candidate Moves in the Levant \\ An Analysis of the Region's Geostrategic Future Using the LAMP Method
}

\author{
Nicholas Lusas \\ INTL504 Analytics I \\ Dr. Jonathan S. Lockwood \\ American Military University \\ July 23, 2009
}

"Our primary assumption in our fight against Israel states that the Zionist
entity is aggressive from its inception, and built on lands wrested from their
owners, at the expense of the rights of the Muslim people. Therefore our
struggle will end only when this entity is obliterated. We recognize no treaty
with it, no cease fire, and no peace agreements, whether separate or
consolidated."

-from “Hezbollah Program”, 1988 ([Sheikh Fadlallah?]) 


\section{Introduction}

The conflict between Israel and its neighbors has been one of the defining conflicts of the last 70 years. The history of the State of Israel began inauspiciously in 1948 as the fledgling nation's Arab neighbors declared war and invaded on the very date of the nation's formation. Since then, the relationship between Israel and its neighbors has been contentious, and tens of thousands have been killed in the wars that ensued after 1948.

The first stages of the conflict were carried out by nation-states. Nations such as Egypt, Syria, Jordan, Iraq, Lebanon, and Morocco participated in a series of wars in an attempt to destroy the Israeli government. These wars against Israel proved disastrous for the Arab states, despite Soviet sponsorship, superior numbers, and even tactical surprise in 1973. The war in June 1967 resulted in Israel obtaining the entire Sinai Peninsula, the Gaza Strip, the West Bank, and the Golan Heights. It also marked the beginning of a shift in the Arab strategy against the Jewish state.

The Israeli occupation of the Gaza Strip and the West Bank, in particular, gave prominence to the Palestinian Liberation Organization, founded in 1964 by the Arab League. Yasser Arafat's Chairmanship of the PLO defined the movement as the chief non-state opposition to Israel, bolstered by Arafat's Fatah militia. As the PLO softened its stance vis-à-vis Israel in the years preceding the Oslo Accords, other Palestinian groups emerged to take on a more militant role against Israel, such as Gaza-based Hamas and Islamic Jihad.

Fatah's operations moved from Jordan to Lebanon during the 1970s. The frequent attacks from Lebanon sparked an Israeli invasion in 1982, the repercussions of which are still felt today. Fatah and the PLO were successfully driven out of southern Lebanon, but a host of new militias emerged, the most significant of which is Hezbollah. 
Hezbollah was founded in the years following the Israeli invasion with the stated goal of driving Israel from Lebanon and establishing a stronger Islamic voice within Lebanon ([Sheikh Fadlallah?] 1988, under "The Necessity for the Destruction of Israel"). The Israeli government authorized a partial withdrawal from Lebanon but maintained forces in a "security zone" that spread out across southern Lebanon. The Israel Defense Forces (IDF) found itself constantly besieged by Hezbollah forces throughout the duration of its deployment, and in 2000, Prime Minister Ehud Barak authorized the full Israeli withdrawal from Lebanon.

After the Israeli withdrawal and a UN certification, Hezbollah's primary raison d'être vanished. Israel had successfully been driven out of Lebanon. It was at this time that a focus on "liberating Palestine" became a focus of Hezbollah rhetoric against Israel, and Hezbollah continued to amass arms for a future conflict with Israel (Wachter 2002, 2).

That conflict erupted in 2006 after a Hezbollah cross-border raid resulted in the capture of two IDF soldiers. The Israeli response followed quickly, and produced devastating effects on southern Lebanon, but the 33-day war against Hezbollah failed to recover the soldiers. Despite sentiments that Israel lost the war, Hezbollah suffered significant losses in both manpower and goodwill among the Lebanese public. Extensive recovery efforts revealed significant damage to Lebanese infrastructure, for which many Lebanese held Hezbollah responsible (Amnesty International 2006).

Hezbollah's struggle against Israel and its allies has not been limited to the battlefield. The FBI has named Hezbollah as the chief suspect in the 1983 Marine Barracks bombing in Beirut that left 283 Marines dead (Federal Bureau of Investigation 2005). The Argentine government has accused Hezbollah for a series of bombings against Israeli and Jewish targets in Buenos Aires, Argentina in 1992 and 1994 that left 114 dead (BBC News B 2006). 
This conflict has a great deal of significance to the world at large. Of Israel's adversaries in the Arab world, only Hezbollah has both the willingness and ability to fight Israel for a protracted length of time. The conflict acts as the perhaps the most destabilizing element in the Middle East, owing to the high probability of renewed hostilities.

The 2006 war between Israel and Hezbollah drove gas and oil prices up to record highs as speculators grew concerned that the conflict might entice oil suppliers in the Arab world to crimp output in an attempt to pressure the United States to reign in Israel (See Appendix A). The conflict is disruptive to American efforts at rapprochement with Iran, who uses Hezbollah as a means to expand its influence in the Middle East and remains the group's chief sponsor. Renewed conflict between Hezbollah and Israel could further galvanize Arab opinion against Israel and the United States, the latter of which is still perceived as the enabler of the former.

The possibility of war between Hezbollah and Israel is of keen interest to the global community, but Israel, the United States, and Lebanon in particular. These three nations are more significantly impacted by the prospects for another war than any other nation. Predicting possible responses by these nations to Hezbollah's actions serves as a capable predictor of the actions that Hezbollah might take and should give an indication of the designs that Hezbollah may have within Lebanon itself after its March 8 Coalition failed to win a parliamentary majority during the June 2009 election (Dickey 2009).

\section{Literature Review}

There is a wealth of current information about Hezbollah and Israel's conflict, owing in large part to the dramatic nature of the 2006 conflict. The vast majority of the English-language literature is written from the perspective of Western authors, and Israelis in particular. Despite the Western authorship, there is useful literature that addresses the conflict from the Hezbollah 
perspective, which is no doubt a result of Hezbollah's extensive media efforts to legitimize its existence as a counterbalance to Israel's power in the Levant.

Literature that addresses the prospects for war between Israel and Hezbollah are abundant, but out of date in some respects. Much of this kind of literature was written in the aftermath of the assassination of Imad Mugniyeh, with the prediction that his death might be the kind of watershed event that would lead to imminent war between Hezbollah and Israel. Despite Hezbollah threats for revenge, there have been no retaliatory attacks. Rather, Hezbollah and Israel negotiated an exchange of prisoners and bodies in 2008, apparently diffusing the pressure that had existed in the aftermath of the Mugniyeh killing.

The amount of literature regarding Hezbollah's relationship with the Lebanese government is not as abundant as the literature addressing the conflict with Israel. Hezbollah's attempts to legitimize itself as a member of the recognized Lebanese government are a relatively recent development, the future of which is uncertain. This development is regarded as tertiary to the group's conflict with Israel and relationship with Iran, which explains the relative paucity of literature on the topic.

The relationship between the United States and Hezbollah is scarcely documented. The United States regards the group as a terror group and has no official lines of communication open with the group. While the United States shares a history with Hezbollah because of the 1983 bombing, the relationship between the two exists only through American influence on Israeli decision-making regarding potential conflict with the group. The United States has supported the March 14 Alliance, a political opponent of Hezbollah.

Norton writes perhaps one of the most comprehensive looks at Hezbollah. He argues that Hezbollah has become a fixture in Lebanon, and that the future of the country is irrevocably 
connected to the group. His extensively researched work chronicles the formation of Hezbollah during the tumultuous Lebanese Civil War in the 1980s, and relates the developments within the group through the months following the end of the 2006 war with Israel. A new afterword comments on the events of early 2008, including the assassination of Imad Mugniyeh, the May 2008 clashes between Hezbollah and the Lebanese government, and the implications of the Doha Agreement. He uses primarily qualitative research methods including personal interviews with members of Hezbollah, its supporters, and other key figures within Lebanon, which is complimented by research from other scholarly sources. Norton states that "the threat of a new war cannot be ignored, even if either Israel nor Hezbollah seem particularly anxious for it to erupt" (Norton 2007, 172). Norton's work is remarkably balanced despite the Western origin of the author, and his experience as a military observer in Lebanon and frequent visitor to Lebanon, when combined with his extensive research, lend his work a considerable amount of authority.

Salem elucidates the situation in the weeks following the 2006 war between Israel and Hezbollah. He argues that the probability for renewed war is predicated on the extent of Lebanon's recovery from the war in 2006. Interestingly, he notes that the 2006 war ended with the signing of a diplomatic resolution rather than simple military disengagement, which is a contrast to the two previous Israeli actions in Lebanon. Salem addresses the perceptions of regional players Israel, Lebanon, Syria, Iran and also the United States. In his analysis, he chooses to frame the 2006 war and prospects for future hostilities through the lens of the destruction caused to Lebanon during a full-scale invasion. In doing so, he is strongly implying that Lebanon's recovery from this destruction will play a significant role in the potential for new war to erupt. Despite the extensive damage to Lebanon, Salem is optimistic in his article that Lebanon will be able to overcome its predicament. 
Sullivan writes an article that aspires to provide a picture of the geostrategic condition in the Levant. He argues that Hezbollah is a key destabilizing factor in the region and that the group's rearmament bodes ill for prospects of peace in the future, stating that the group has surpassed the capabilities it possessed during the 2006 war with Israel (Sullivan 2008, 126). Sullivan argues that renewed hostilities between Israel and Hezbollah will destabilize the Middle East, potentially to the point the war takes on wider, regional dimensions (Sullivan 2008, 132). Sullivan's article is the result of research and interviews with "geostrategic players inside and outside of Lebanon" (Sullivan 2008, 132).

Bar focuses his analysis of the conflict on the role that deterrence will play in the strategic decision-making of Israel and Hezbollah. Bar asserts that the 2006 war erupted due to a failure, or negligence, by Israel to effectively communicate the "rules of the game" (Bar 2007, 487). He argues that Hezbollah received no signals that would have alerted them to the fact that the scope of the July 12, 2006 raid was beyond that which Israel would tolerate. He mentions Nasrallah's now well-known position that he would not have authorized the attack had he been aware of the potential consequences. He argues that the 2006 war represented an unusual level of escalation in the conflict and implies low probability to the occurrence of another conflict on such a massive scale. Bar's article is the result of scholarly research and intuitive analysis, and provides a perspective on the conflict between Israel and Hezbollah that is uncommon in the existing literature on this topic.

Honig addresses the Israeli policy of deterrence. He gives a brief history of the concept as developed by David Ben-Gurion, and chronicles the changes in the doctrine as Israeli defense establishment learned from the experiences of decades of both large-scale conventional war and low-intensity conflict. He divides the evolution of Israel's deterrence doctrine into three distinct 
periods, which are demarcated by the founding of the State of Israel, the signing of the Oslo Accords, and the 2006 war with Hezbollah. He argues that the Israeli policy of restraint during the 1990s while pursuing a peace settlement with the Palestinians ultimately failed. $\mathrm{He}$ characterizes the Israeli response that led to the 2006 war as a watershed moment, signifying a shift in Israeli strategy back to the classic deterrence doctrine that exemplified Israeli military action before the 1990s. He calls Hezbollah's attack that precipitated the 2006 war a "miscalculation" by Nasrallah (Honig 2007, 70). He insists that both Israel and the United States have lessons to learn from the "failure of Western restraint on Hezbollah", essentially endorsing strong responses by Israel and the United States to Hezbollah's provocations (Honig 2007, 71). He recommends that Israel continue its policy of deterrence, but warns that,

"If deterrence is to work, though, Israeli politicians must make a sustained rather than episodic commitment to the doctrine. A disproportionate response to terror should be the rule, not the exception." (Honig 2007, 71)

Honig's article is unique among the majority of literature on this topic because of its relatively unflinching advocacy of a strategic stance that is likely to result in another large-scale conflict.

Much of the literature on this topic makes the rather grim prediction that renewed hostilities are inevitable. Though much of the literature on the topic makes general predictions of imminent war between Israel and Hezbollah, predictions about how a new war would come about are scarce. Moreover, predictions about exactly what a new war might look like and the consequences of a war are also very scarce. For this reason, this analysis will focus on the potential causes for war, and also seek to analyze the consequences of the future decisions by Hezbollah, Israel, the United States, and Lebanon. This type of analysis will require a methodology that emphasizes the analysis of the decisions that these actors make and their consequences on not only the future, but also the decision-making process of other actors. 


\section{Methodology}

This predictive study will be conducted using the Lockwood Analytical Method for Prediction (LAMP method). The LAMP method is well suited to this analysis because this method is well suited to the international focus of this study. The LAMP method incorporates elements from other processes, but the strength of the method for this study lies in the adaptability of the analysis to the choices of actors that arise from changing circumstances. The emphasis on creating characterizations for each actor allows the analyst to understand the actors, and lends insight into the decision-making process of each actor in a given scenario. The lack of quantitative methodology lends flexibility to the analysis.

The LAMP method was selected over other familiar methods such as the Delphi Technique and the Analytical Hierarchy Process (AHP). The Delphi Technique, while an effective technique for prediction and understanding in its own right, involves a process that is beyond the scope of this author to pursue. The AHP is a popular problem-solving method, but is problematic for the purposes of prediction. On an issue as complicated as the prospects for war involving Hezbollah, Israel, and the United States, the AHP method would prove rather unwieldy, time-consuming, and ultimately of limited value, given the quantitative nature of the method and the tremendous potential for bias.

The Probability Tree Analysis (PTA) can be an effective tool for prediction, but relies too heavily on numbers supplied by the analyst that, despite the best efforts of the analyst, are too arbitrary to be truly useful for this kind of study. The number of actors involved in this study makes the PTA method, which is better suited to a head-to-head analysis, prohibitive. While a study can be done using multiple actors by using multiple trees, the ability to analyze the effects 
that one actor's decisions have on another actor is hindered by the head-to-head nature of the analysis.

There are twelve steps to the LAMP method. The focus of the analysis moves from the general to the specific, with emphasis on divergent thinking in the early stages and on reviewing the consequences of each alternate future in the latter stages. The twelve steps of the LAMP method listed here reflect the list as it is presented on the LAMP method website:

1. Define the issue for which you are trying to determine the most likely future.

2. Specify the national "actors" involved.

3. Perform an in-depth study of how each national actor perceives the issue in question.

4. Specify all possible courses of action for each actor.

5. Determine the major scenarios within which you compare the alternate futures.

6. Calculate the total number of permutations of possible "alternate futures" for each scenario.

7. Perform a "pairwise comparison" of all alternate futures to determine their relative probability.

8. Rank the alternate futures for each scenario from highest relative probability to the lowest based on the number of "votes" received.

9. Assuming that each future occurs, analyze each alternate future in terms of its consequences for the issue in question.

10. Determine the "focal events" that must occur in our present in order to bring about a given alternate future.

11. Develop indicators for the focal events.

12. State the potential of a given alternate future to "transpose" into another alternate future (Lockwood 2008).

The LAMP method is particularly suited to a predictive analysis of the Middle East. The complications of the Israeli-Arab conflict produce a divergent array of opinions among not only the participating actors, but also among observers, making the conflict one of the most contentious in the world. The qualitative nature of the LAMP method provides an advantage over other methods that favor a quantitative method, 
where seemingly unbiased numbers are analyzed, but are applied by a process has plenty of opportunity to introduce bias.

Despite the advantages of the LAMP method, the potential for bias still persists within this study. The nature of the Israeli-Arab conflict, so often portrayed in good-evil and black-white polarities, brings out strong reactions to developments, and opinions, once formed, remain firmly entrenched against a media onslaught, which supports one side or another. Despite the author's attempts through the years to study both sides of the conflict, including language, religion, and culture, there are likely to be perceptions on one side or the other that elude the author. The author, having been raised in the United States and educated only within the United States and Canada may have an underlying bias, whether unconscious or conscious, that may permeate the analysis. Despite reservations on this matter, the author has made every attempt to mitigate bias in the study.

This effort to mitigate bias will affect the author's choice of terms when referring to past conflicts. One dynamic of the polarities that exist within the Middle East is the frequent practice of both sides using a different name for a given conflict. For example, the war in 2006 between Israel and Hezbollah is called by different names in Lebanon and Israel. In Lebanon, this war is called the "July War", and in Israel it is called the "Second Lebanon War". Similar naming discrepancies occur when referring to the Israeli-Arab wars in 1948, 1967, and 1973. In an effort to demonstrate impartiality, these wars will simply be referred to by the year in which the war occurred. For example, the war in 2006 will simply be referred to as such or as "the 2006 war". Fortunately, there are no cases in this analysis during which there were two relevant wars in a given year. 
However, the context of the war will be made apparent regardless of this and all efforts have been made to ensure clarity while maintaining impartiality in the terminology used in this analysis.

\section{Actors and Perceptions}

While the conflict between Israel and Hezbollah is of interest to the world as a whole due to the wide repercussions of the conflict, there are four actors that are most affected by the course the conflict may take in the future. Hezbollah, Israel, the United States, and Lebanon are the actors whose perceptions and decisions will directly affect the future of the conflict. Studying and understanding the perceptions of each actor will provide insight into how the prospects for war or peace affect them and how their decision-making process is shaped by these perceptions and the events that unfold.

Each actor's perceptions will be analyzed through the lens of three areas of consideration for each actor, which in this analysis are derived from each actor's political, economic, and security situation. Social considerations directly affect the politics and security of each actor and the implications of social sentiment will be addressed as it relates to those considerations. Including social considerations on its own would provide little additional utility to the study. Likewise, the same applies to religious considerations, which are obviously of immense importance in its own regard in the Middle East, but merely an element, no matter how significant, in the wider political and security considerations already outlined. Despite the intense media and anecdotal focus on the religious background of the conflict, this study has resisted the impulse to include these as individual considerations that override or share equal an equal level of 
consideration with the more pragmatic political, economic, and security considerations of each actor.

\section{Hezbollah}

The LAMP method specifically calls for national actors in its analysis. Hezbollah presents an interesting dilemma in the regard because it is not recognized by any organization as a national entity. However, Hezbollah does possess many of the elements of a national actor. The group maintains a standing military, with many times more the number of reserves available for combat if required (GlobalSecurity.org A). The group has administrative divisions that provide social programs, health facilities, and education facilities for significant portions of the Lebanese population, particularly in the southern part of the country. The group has taken a proactive posture in rebuilding parts of Lebanon devastated by the 2006 war with Israel. In these regards, Hezbollah actually provides many services to the people of Lebanon that the Lebanese government has difficulty providing, including security in the southern and Bekaa Valley regions of Lebanon. These characteristics have led observers in Israel and the United States to call Hezbollah a "state within a state", and serve to separate the group from other groups that are merely military in nature, such as Al Qaeda, Abu Sayyaf, and Islamic Jihad (Magouirk 2008, 358). It is for this reason that Hezbollah represents a viable group for consideration as a national actor for the purposes of the LAMP method.

\section{Political}

Despite Hezbollah's perception as a military group first and foremost, the group has struggled to attain and maintain political legitimacy within Lebanon. The group first participated in Lebanese elections in 1992, winning 12 seats out of 128 in the Parliament 
(Norton 2007, 101). Hezbollah has participated in each election since and currently holds 12 seats within the Parliament following the June 2009 elections, having lost two seats since the 2005 elections.

Despite the relatively low percentage of seats within the Parliament, Hezbollah is a very powerful group in Lebanese politics. This is partly a result of the group's military power and because the group enjoys popularity that transcends the traditional sectarian divides in Lebanon. The group's participation in the Lebanese political process has not precipitated a move to disarm its militia as the rival Amal movement has done. Hezbollah regards itself as the defender of Lebanon against Israel, and has used this pretense to maintain its vast arsenal of weapons.

Hezbollah is a leading member of the March 8 Coalition, which is the antagonist to the Western-leaning March 14 Alliance. The March 8 Coalition was formed during the Cedar Revolution to counteract the rising anti-Syrian sentiment in Lebanon following the assassination of outspoken Syrian critic, Rafik Hariri. The Coalition supports greater Syrian influence in Lebanon, and despite winning the popular vote in Lebanon, did not obtain a majority in the Lebanese parliament in the June 2009 elections. This development has been perceived as a victory for the March 14 Alliance in Western circles, but the results support the idea that popular sentiment in Lebanon resides with Hezbollah and the March 8 Coalition.

Hezbollah was founded with aid from Iran, and retains strong connections to Tehran. The group's initial membership trained under Iranian auspices (Nasr 2006, 115). The Hezbollah chain of command recognizes the Supreme Leader of Iran as the ultimate leader of the group, though the Lebanon-based Shura oversees the group's day-to-day 
activities. Few decisions are actually made or approved by the Iranian Supreme Leader and are generally limited to military decisions regarding Hezbollah engagement with Israel (Hamzeh 1993). Iran supplies Hezbollah with financial and military support in the form of advanced weaponry.

Hezbollah maintains strong ties to Syria, a relationship that dates to the days of heavy Syrian influence in Lebanon during the 1980s. Since the Syrian withdrawal from Lebanon in 2005, the balance of power in the relationship has tipped in favor of Hezbollah. This development stems in part from Syria's inability to directly affect Lebanese affairs as effectively as it had in the past. The close relationship between Damascus and Hezbollah allows the former to wield greater influence in Lebanon through the increasing power of the latter. Hezbollah's upper hand in the relationship stems perhaps more poignantly from the insecurity of Bashar al-Assad, whose hold on power is more tenuous than that of his late father, Hafez. His support of Hezbollah enables him to retain legitimacy as the ruler of Syria through the perception that he is supporting Islamist causes (Bar 2007, 471).

Hezbollah's status as a Shia party with a well-known connection to Iran and Syria has not stymied the group's popularity with other religious groups in Lebanon, the Christians and Druze in particular. This is the result of the group's more inclusive outlook that mirrors that of Khomeini rather closely, but is also the result of a pragmatic approach by the group that reflects the reality of Lebanese pluralism (Nasr 2006, 137). The group's steadfast devotion to protecting Lebanese territorial integrity in the face of Israeli occupation before 2000, and invasion in 2006 has endeared the group to a significant and growing portion of the Lebanese population. 


\section{Economic}

Hezbollah receives the lion's share of its funding from Iran. The developments in Iran following the June 2009 elections could threaten the flow of money and military support, particularly if the developments in Iran lead to the eventual overthrow of the Islamic regime. Despite Tehran's success in quelling the protests in the streets, popular sentiment appears to have irrevocably turned against the regime in a scene reminiscent of the months preceding the overthrow of the Shah. However, despite these developments, the flow of aid from Iran to Hezbollah remains steady as of July 2009.

Hezbollah has invested the aid in diverse ways. Hezbollah has invested heavily in social programs and health facilities for Lebanese citizens that would otherwise not have access to the level of care that Hezbollah's facilities provide. The group followed through on its promise after the 2006 war to take on a lion's share of the financial burden for the rebuilding and recovery process (Siegel and Watson 2006).

The greatest threat to Hezbollah's economic position would be a cutoff in the flow of aid from Iran. While this development is not currently in the offing, growing revolutionary sentiment in Iran poses a significant threat to Hezbollah's economic interest. While donations from wealthy sympathizers in the Muslim world can fill some of the gap that would be left without Iranian funding, it is likely to fall far short of meeting Hezbollah's needs for retention of its growing social responsibilities and military expansion.

\section{Security}

The most visible aspect of Hezbollah to observers outside Lebanon is its military wing, Al-Muqawama al-Islamiyya, or "The Islamic Resistance". The name of the 
military underscores its raison d'être. The group's founding purpose and continued mission is to confront and defeat the nation of Israel in a bid to "liberate Palestine", in accordance with its mission statement released in 1988 ([Sheikh Fadlallah?] 1988, under "The Necessity for the Destruction of Israel").

To this end, Hezbollah has obtained a significant arsenal of weapons. The group allegedly maintains an arsenal of rockets, including tens of thousands of Katyusha rockets, as well as Iranian mid- and long-range missiles such as the Fajr-3 and Zelzal missiles, the latter of which are capable of striking deep into Israeli territory, including urban centers such as Tel Aviv (Rao 2006). The group has significant anti-tank capabilities, possessing anti-tank weaponry such as the AT-3 Sagger and Kornet anti-tank rockets, which performed relatively well against the state-of-the-art Merkava IV (MkIV) Israeli Main Battle Tank (MBT) during the 2006 war (Stratfor 2006).

Hezbollah relies on a strategy of mutual deterrence with Israel. Israel's immense military power and ability to deliver a punishing blow to Lebanon represents the chief method of deterrence for Israel. Hezbollah's deterrence resides primarily in its ability to threaten Israeli population centers with its vast rocket arsenal. This strategy proved dramatically successful during the 2006 war as Hezbollah's rocket barrage against Israel effectively shutdown the northern third of the country throughout the duration of the 33day conflict. Hezbollah's other avenue for deterrence lies in the group's threats to carry out terror attacks against Israeli and Jewish targets around the world. Hezbollah's successful bombing of Jewish targets in Argentina in 1992 and 1994 enhances these threats and provides the locus for this kind of deterrence. 
Hezbollah's military strategy against Israel is best determined by the actions the group has taken in the past to successfully engage Israel. The theory is that the group would again use the methods that have proven successful until the IDF can demonstrate the ability to defeat these measures. Hezbollah's engagement of Israeli forces in the years preceding the Israeli withdrawal in 2000 and in 2006 provides the greatest insight into the group's methods for conducting future wars against Israel.

Hezbollah retains a two-tiered strategy for engaging Israel. One tier of the strategy is applied to fighting within Lebanon, and the other is applied to Hezbollah's media strategy. The strategy for engaging IDF forces within Lebanon appears to focus on drawing IDF soldiers into urban areas where the potential for IDF casualties increases dramatically. Urban areas further provide Hezbollah an opportunity to kidnap IDF soldiers to use as bargaining chips in prisoner exchanges not unlike the exchange that occurred in 2008. As IDF casualties mount, the hope is that the war would become less popular among the Israeli public who would demand a quick end to the conflict.

The media strategy against Israel during a war is controversial and hotly disputed. This is a topic with ample possibility to introduce bias. Despite this, there are strong indications that Hezbollah's strategy is to pursue a media strategy in an attempt to turn global opinion against Israeli action and put pressure on Israel to abandon its assault on Hezbollah. The strategy involves placing fighters and targets in urban areas in an effort to either deter Israeli engagement or invite Israeli fire that might inadvertently result in civilian casualties, producing a media victory for Hezbollah by way of Israeli culpability in the death of innocent civilians. While this strategy appears to have been successful in turning global sentiment against Israel, there is potential that such a strategy could 
blowback on Hezbollah if incontrovertible proof of the group's intentions were to come to light. Israel's often-ineffective attempts to defend its actions have yet to mitigate the effectiveness of this strategy.

Hezbollah does not have illusions that its military power can surpass or even match that of Israel. Instead, the group operates on the premise that it has sufficient military power to suppress Israel's appetite for a protracted war in such a way as to make Israeli action against Hezbollah unlikely (Bar 2007, 471). The group's steadfast refusal to disarm stems from the perception that only with a well-armed militia in southern Lebanon can the nation hope to retain its territorial integrity against the powerful IDF.

\section{Israel}

Israel is an obvious choice for inclusion in this analysis. Israel is Hezbollah's primary adversary, and Hezbollah represents a significant strategic threat for Israel. The nation's very existence provides Hezbollah with the grounds for the maintenance of its military wing. Israel and Hezbollah have fought each other for more than 15 years in a low-intensity combat situation until the IDF withdrawal from Israel's self-described Security Zone in southern Lebanon in 2000. The war in 2006 with Hezbollah represents one the largest Israeli military operations in the last 25 years. No predictive analysis of Hezbollah's decision-making process would be considered valid without a study of Israel's perceptions and reactions to Hezbollah's strategic and tactical maneuvers.

\section{Political}

Israel's political leadership has undergone significant change over the last ten years as Israelis struggle to find the appropriate response to the changing security situation in the country. The optimistic attitudes that prevailed in the 1990s as the nation 
seemingly moved toward a peaceful coexistence with its Palestinian neighbors was shattered in 2000 after the Camp David summit ended with no agreement and triggered the second Palestinian Intifada.

The political fallout from this development was the marginalization of the Labor party, which had advocated a dovish approach toward the Palestinians in favor of the right-leaning and more hawkish Likud party. In the 2009 general elections, the Labor party finished fourth among all parties, while the right-wing Likud and Yisrael Beitenu parties achieved significant gains in the Knesset (Israel Ministry of Foreign Affairs 2009). Israeli commentator Gil Troy attributes this shift in attitude to growing Israeli cynicism regarding Palestinian and Hezbollah provocations that instead of softening Israeli resolve have had the reverse effect, pushing Israelis toward the right (Troy 2009).

The 2006 war with Lebanon had profound effects on the political makeup of the Israeli leadership, which at the time was dominated by the center-right Kadima party. Prime Minister Ehud Olmert, who enjoyed support for his decision to go to war, achieved anemic approval ratings that hovered near 3\% in the months following the war (Time Magazine 2007). The Winograd Report, which provided a critique of the Israeli leadership during the war, placed the blame for the war's shortcomings on the shoulders of Olmert, IDF Chief of Staff General Dan Halutz, and Defense Minister Amir Peretz (Haaretz 2007). All found their political careers utterly derelict. Foreign Minister Tzipi Livni attempted to distance herself from the other maligned members of the government, with limited success. Her run for Prime Minister in 2009 fell short, narrowly losing to Likud candidate and former Prime Minister Binyamin Netanyahu. Her association with the 2006 war and the Kadima party undermined her defense credentials at a time when 
Israel was looking for a solution to the many threats to Israel's security. The voting pattern of the 2009 election appears to indicate that the Israeli populace would support a harder line on the Israeli security posture.

Israel has official relations with only two Arab nations, Jordan and Egypt. Even the relationship between Israel and these two nations have proved tumultuous at times, and neither head of state has visited Israel. Some Arab nations have maintained communications with Israel on unofficial channels, but normalization of relations between Israel and the Arab world has not yet occurred.

Israel's relationship with the European Union is cordial but, at times, contentious. France and Spain are frequent critics of Israeli policy, while nations such as Germany and Great Britain are not nearly as critical of Israel. The concerns of European nations stem chiefly from perceptions that Israel employs "disproportionate response" when responding to Palestinian or Hezbollah provocations. The European Union firmly objects to the Israeli blockade of Gaza, and the issue has become a stumbling block to warmer relations between the two.

Israel's chief allies are the United States and India. Of these two, Israel has enjoyed a fuller and more fruitful relationship with the United States, who has supplied aid, military, and moral support at a higher level than any other nation since the war in June 1967. Despite these close relations, Israeli perceptions of the alliance with the United States have grown pessimistic during the first months of the administration of President Barack Obama. Contention centers on growing American insistence that Israel abandon further construction of settlements in the West Bank. The Israeli perception is that the United States is demanding that Israel take more steps toward peace than it is 
willing to ask of the Palestinians. Obama's trip to the Middle East involved a keynote speech in Cairo but no visit to Israel, which has annoyed and disturbed Israeli observers. Members of the Likud party called on members of their party to boycott a traditional July $4^{\text {th }}$ celebration in Jerusalem as a show of frustration with American policy.

Israel's relationship with India existed only in an informal capacity until 1992. Since then, Israel has surpassed Russia as the chief arms supplier to India, and the two nations have cooperated on a joint space program (BBC News C 2008). India and Israel share a common enemy in the Islamist threat, and have cooperated on counter-terror training and the sharing of intelligence (India Defence 2008). The relationship between the two nations should continue to solidify in the future, particularly if Israeli perceptions regarding the alliance with the United States continue to sour.

\section{Economic}

Israel's economy is strongly tied to the Western markets and has suffered as a result of the global recession. Israel's tourism industry, a key pillar of the Israeli economy has suffered since the start of the second Intifada in 2000 and has never fully recovered. The 2006 war with Hezbollah only exacerbated concerns that tourists could be trapped in a dangerous situation in what is perceived as a volatile region.

As of the summer 2009, Israel remains embroiled in a water crisis due to a severe drought. Desalination plants along the Mediterranean now account for $15 \%$ of Israel's drinking water production and this number is expected to increase as the water levels decrease in the Sea of Galilee (Mizroch 2008). The population of Israel is projected to increase due to both immigration and the growing Arab population, compounding the problem for the foreseeable future. The water crisis underscores the Israeli presence on 
the Golan Heights, which prevents Syria from damming off the runoff from Mount Hermon, which supplies the water for the Sea of Galilee (Eshel 2008). As long as the water crisis remains a priority in Israel, the country is unlikely to consider any peace deal with Syria that includes the handover of the disputed territory.

Israel receives financial aid from the United States. The aid amount is significant and constitutes 3\% of the Israeli GDP (Feith 2003). During his first term as Prime Minister during the late 1990s, Netanyahu attempted to push through legislation to reduce the American contribution and steadily phase it out (Feith 2003). However, this initiative did not survive his term as Prime Minister, and Olmert actually pushed for increased aid during his term as Prime Minister (Reuters UK 2007). Approximately $\$ 2$ billion of the American aid to Israel is earmarked for expenditure on weapons manufactured within the United States (Feith 2003).

Israel still retains its reputation as a High Tech center. Israeli economic connections with the United States have been further strengthened by Israeli-American cooperation on High Tech projects in the computer science field and medical profession in particular. Israeli exports of High Tech equipment and knowledge are a significant boon to the Israeli economy.

Israeli dependence on foreign oil remains high, but the nation is taking steps to curb its dependence on foreign energy. Renault and Nissan have partnered on a project to introduce an all-electric-powered car into the Israeli market by 2010. The plan calls for the introduction of the vehicle as well as infrastructure to make the vehicle viable for widespread use throughout the country, including battery depots and charging stations at various locations throughout Israel. The project's development is in the intermediate 
stages (Nissan 2008). If Israel is able to implement this vision, it will lend the nation considerably more flexibility in its decision-marking process on matters of national security.

\section{Security}

Israel possesses the most powerful indigenous military in the Middle East. The military has held the reputation of invincibility when facing conventional Arab armies due, in large part, to Israel's stunning victory over several Arab armies in 1967. Arab attempts to surprise Israel in 1973 achieved small gains that were later mitigated by the IDF counteroffensive.

The IDF possesses state-of-the-art equipment, the majority of which is either indigenous or comes from the United States. The Israel Air Force (IAF) consists primarily of United States' produced aircraft augmented with Israeli targeting and navigation systems (GlobalSecurity.org B). IAF pilots are highly regarded internationally, and enjoy the perception of invincibility, a perception that also has roots in the 1967 war. IAF pilots are widely regarded as being among the best in the world.

The IDF armored corps largely consists of indigenous tanks or retrofitted tanks that were captured in previous wars with Soviet-sponsored Arab states. The current Israeli MBT is the MkIV, an indigenous design that emphasizes crew survivability in the event that the tank is hit by rocket fire (Hughes 2006). The performance of the MkIV in 2006 was generally good despite some stiff Hezbollah resistance, with a few MkIV tanks lost to Hezbollah rocket fire. In a country that cannot tolerate excessive attrition, the survivability of the MkIV provides commanders, soldiers, and the Israeli public with assurance that casualties will be further decreased in future designs. 
Israel possesses extensive collections capability through its airborne and satellite reconnaissance programs. This capability affords IDF commanders the capability of being able to spot enemy positions and accurately allocate IDF resources on the battlefield. This collections capability affords IAF planners the ability to plan out air missions and campaign strategy well in advance of the actual renewal of hostilities, permitting the IAF to spring into action quickly. The IAF demonstrated this ability in the early hours of the 2006 war, hitting key targets in Lebanon within hours of the Hezbollah ambush on and kidnapping of IDF soldiers.

Despite the IDF's extensive capabilities, the military has not found a satisfactory way to address indiscriminate rocket fire. Hezbollah fired rockets indiscriminately into Israel during each day of the 33-day conflict, inflicting minimal damage, but having a tremendous psychological impact on Israeli residents in the northern part of the country. Hamas has made use of indigenously produced Qassam rockets to achieve the same affect on Israeli towns near Gaza, particularly Sderot. The IDF's inability to halt the rocket fire coming from either group has unnerved the Israeli public and provides both Hezbollah and Hamas with a way of attacking Israel that is effective and inexpensive.

The rocket fire notwithstanding, the IDF performance in the 2006 war against Hezbollah was lackluster. While Israel formed the Winograd Commission to investigate the war, Hezbollah claimed to have shattered the myth of IDF invincibility through its self-described "divine victory" (MSNBC 2006). The psychological impact of this development has had a lasting effect on the Israeli public, though the generally solid performance of the IDF in the war against Hamas in December 2008 and January 2009 mitigated many concerns on the IDF's fighting capability. Though the IDF suffered a 
blow to its reputation, the Israeli public remains confident that the IDF has been able to correct its shortcomings. The election of Netanyahu, who would ostensibly be more apt to put the IDF into action, underscores the renewed confidence that the Israeli public places in the IDF.

Israel's intelligence establishment has a reputation for excellence in both its collections and operations capabilities. While there is debate on the true nature of Israel's intelligence capabilities, the counter-terror record is generally good. Recently, Azerbaijani intelligence helped uncover a Hezbollah plot to carry out a terror attack against a Jewish target in Baku, Azerbaijan (Trend News). The 2007 operation to destroy an alleged Syrian nuclear facility surprised many observers and is regarded as a success for Israeli intelligence and special forces (Sanger and Mazzetti 2007). Hezbollah has attributed the assassination of its commander Imad Mugniyeh to the Israeli intelligence agency Mossad. Despite the fact that Mossad has not claimed responsibility for the killing, the perception that Israeli intelligence is capable of carrying out such an operation demonstrates the confidence that both Israel and its adversaries place in the capabilities of Israeli intelligence.

Israel depends on a policy of strategic deterrence. David Ben-Gurion, who believed that Israel could not survive a war of attrition on its own soil, formulated this strategy in the days following the first Israeli-Arab war in 1948. He postulated that the best way to prevent a constant barrage of Arab assaults was to retaliate for attacks in such a way as to discourage further assaults against the Jewish state (Honig 2007, 63). To implement this strategy, the IDF has relied on a policy of disproportionate response to 
Arab attacks and provocations in an effort to reduce their likelihood in the future. Israel's policy of nuclear ambiguity adds another dimension to its deterrence posture.

Israel's strategic deterrence doctrine has enjoyed a degree of success. The 2006 war's affect on Israeli deterrence is difficult to determine. While the IDF's performance in the war was lacking, the scope of the Israeli response surprised Hezbollah, and the group's Secretary General, Hassan Nasrallah, commented that had he foreseen the response, he would not have authorized the attack that triggered the war (Naharnet 2006). Hezbollah's disinclination to attack IDF forces in the first three years after the end of hostilities, coupled with the IDF's show of force in Gaza in January 2009, indicate that Israel enjoys a at least a modicum of strategic deterrence.

\section{United States}

The United States has retained a keen interest in the Middle East and Israel in particular since the Suez Canal crisis of 1956. The Soviet Union's support for Arab governments during the 1960s compelled the United States to support Israel, as the lone democracy in the region. Since the 1960s, Israel has been the United States' chief ally in the region, and American influence on the Israeli decision-making process has been significant, even if not always consistent.

The United States and Hezbollah have a limited but bloody history. The 1983 bombing of the Marine barracks in Beirut, blamed on Hezbollah, spurred the departure of American forces from Lebanon. Hezbollah occupies a spot on the American list of terror groups, chiefly as a result of the 1983 bombing and 1994 bombings of Jewish targets in Argentina. 
American perceptions of the conflict between Israel and Hezbollah are significant. Because the United States designates Hezbollah as a terror group and enjoys a strong alliance with Israel, the United States naturally supports Israeli efforts to combat Hezbollah, but traditionally stops short of taking part in the action itself. Whether or not the United States supports Israeli action or is of the opinion that Hezbollah's actions warrant a response plays a large role in whether or not Israel will go to war with Hezbollah. Hezbollah is likely to consider heavily the effect that their provocations and attacks have on American opinion, and are likely to carefully toe the line that divides American calls for restraint versus American endorsement of Israeli action.

\section{Economic}

As of the summer of 2009, the United States is enduring the worst economic crisis in the nation's history since the Great Depression. Unemployment numbers in July 2009 indicate that the recession is likely to continue for lengthy amount of time. The American government has approved two separate stimulus packages since the start of the economic collapse in September 2008, with a total investment of over $\$ 1$ trillion (Recovery.gov). The success of these measures is still unclear, but there is justifiable concern that if these stimulus packages fail to jumpstart the economy, then the American economy could fall farther into recession, perhaps sparking a prolonged economic depression.

Exacerbating concerns about the economy are the unstable oil prices. Since reaching a high of $\$ 147$ a barrel in July 2008 , oil prices tumbled to lows of $\$ 33$ a barrel in December 2008. However, between December and July 2009, oil prices have jumped back up to over $\$ 60$ a barrel (See Appendix A). Instability in Iran failed to push prices higher, but a new war in the Middle East may put irresistible upward pressure on oil 
prices, which could further cripple the American economy and crimp any attempt at economic recovery.

The United States has spent billions of dollars on wars in Iraq and Afghanistan, and while there is a planned withdrawal from Iraq, American government investment in that country will probably continue. As the war in Afghanistan intensifies, the financial burden of conducting the war in Iraq may simply shift to Afghanistan rather than abate. As the American economy continues to decline, economic concerns are likely to weigh ever more heavily on American foreign policy decisions.

\section{Political}

The American political scene has undergone significant changes in the last six years. Republican gains in the House and Senate in the 2002-midterm elections have been reversed by the 2006 midterm and 2008 general elections. The Democratic Party enjoys a "filibuster-proof" majority in the Senate and a significant majority in Congress, and also control of the White House with the victory of Obama over Republican opponent John McCain in the Presidential elections.

Obama set out his Middle East policy, which entails an emphasis on reconciliation with the Muslim world, whose perception of the United States has soured because of the Iraqi invasion and stalwart support for Israel. Naturally, Obama's overtures to the Muslim world have alienated the nation's Israeli allies, and Obama has had to find a way to strike a balance of reconciliation with the Muslim world with ensuring that Israel's security needs are understood and met. Arab states and Muslims in general responded positively to Obama's speech in Cairo on June 4, 2009 (Asharq Alawsat 2009). 
The American alliance with Israel, recent Israeli cynicism notwithstanding, has been strong for over forty years. The United States and Israel share not only a common enemy in violent Islamism, but more importantly a shared democratic vision and tradition. In response to Israeli criticism that the United States is favoring Palestinian demands, Obama has reiterated that the United States takes interest in the security and well being of Israel. Despite the small shift in American policy toward Israel, American perceptions of the Israeli-Arab conflict will continue to be shaped by what Israel and the United States have in common. In the event of a threat to Israeli security, Vice President Joe Biden has expressed the opinion that Israel has the "sovereign right" to act in the best interests of its national security, indicating at least tacit American support for a more assertive Israeli strategic posture, particularly with regard to Iran (Benhorin 2009).

The United States' strong support for Israel has enabled it to act as a mediator in the Middle East peace process. Though the United States is perceived across the Muslim world as having a strong bias toward Israel, the Palestinians recognize that the United States also has an interest in catering to its Arab allies and the ability to strongly influence Israeli decision-making to this end. As a result the United States has taken the lead in trying to push for a settlement in the conflict between the Israelis and Arabs. Despite sometimes-intense effort from the United States, peace has remained elusive, and doubts have emerged about the United States' ability to broker agreements in the Middle East.

Obama had indicated willingness to begin a process of rapprochement with Iran during the Presidential campaign. Iran may feel compelled to take advantage of the softer line from the United States and encourage Hezbollah to take a more aggressive 
stance against Israel, especially if it might deflect attention away from Iran's continuing nuclear program. However, prospects for rapprochement with Iran dimmed in the aftermath of Iran's controversial June 12 elections, during which Ahmadinejad won by an apparent two-to-one margin over reformist candidate, Mir Hussein Mousavi (Al-Jazeera). The regime's brutal suppression of post-election protests and accusations of American interference sparked a war of words between Obama and Ahmadinejad (Kreiger and Amidi 2009).

The perception that Obama is a dove is not necessarily accurate. During the Presidential campaign, he expressed a willingness to take the fight against Al Qaeda and the Taliban into Pakistan if necessary, and American missile attacks into Pakistani territory in early 2009 confirmed his position (Mazzetti and Sanger 2009). While Obama is willing to withdraw from Iraq, he appears, at the same time, rather willing to use force to ensure the national security and interests of the United States.

Despite the many concerns that the United States has in its foreign policy, the economy has captured the focus of the American public and its government. This development was a crucial factor in pushing the American vote away from Republican candidates, who are perceived as possessing stronger national security acumen. The Obama administration has passed a stimulus package, but worries that the administration is faltering in its handling of the economy have driven Obama's approval ratings below 60-percent according to a Gallup poll (Gallup 2009).

\section{Security}

As of July 2009, the United States is entangled in two wars in Iraq and Afghanistan. While the United States military is in the midst of a phased withdrawal 
from Iraq, those resources may be allocated to the intensifying conflict in Afghanistan with a resurgent Taliban. The ability of the United States to withdraw from Iraq on a timely basis and confront the Taliban will determine the degree to which American forces are free to pursue action elsewhere to further the national security and interests of the United States.

The conflict in Afghanistan has spilled into Pakistan, and Obama has made clear that Afghanistan must be a priority for allocation of the military (Cooper and Schmitt 2009). The American national security interest in the conflict with the Taliban is a result of the possibility that a Taliban takeover in Pakistan will result in nuclear weapons falling into the hands of an Islamist faction. The revival of Al Qaeda in the region is another major concern for the United States, amid fears that the revitalized group may attempt another attack on the continental United States, possibly with the use of a weapon of mass destruction (WMD). For this reason, this conflict will likely be considered a priority over any other conflict until the threat to American national security is mitigated.

The United States possesses a military that is capable of meeting a variety of challenges. The American military remains the most potent in the world and is capable of quick deployment due, in large part, to the ability of Naval carrier groups to move quickly to trouble spots around the world. The United States possesses many options to have military forces ready to respond to a Middle East crisis between Israel and Hezbollah, if necessary.

The intelligence collection capabilities of the United States are unsurpassed. This affords American strategists the ability to detect indicators of enemy action quickly and either take appropriate action or alert allies to these developments as needed. American 
collection capabilities, Image Intelligence (IMINT) and Signals Intelligence (SIGINT) in particular, provide the United States with the ability to logistically support any military action undertaken by an ally in a manner that is both significant and deniable. In the Middle East, such a capability is extremely useful if the United States wanted to aid Israel without utterly destroying its credibility as a mediator of negotiations.

Following the 9/11 attacks, the United States has shifted many of its intelligence assets toward countering the terror threat to the country. The continued American pursuit of Osama Bin Laden and Al Qaeda underscores the American focus on mitigating the terror threat. Though Hezbollah has yet to attack American targets on American soil, the 1983 Marine barracks bombing remains etched in the minds of Americans. Any Hezbollah attack that directly affects Americans or American interests is sure to draw some kind of response from Washington.

The United States would certainly have doubts about committing to another military operation while still deployed in Iraq and Afghanistan. The sheer costs of those operations make the opening of another war prohibitive, if not politically suicidal, in the current economic climate. As the Iraqi withdrawal draws toward completion and if the military can make headway against the Taliban in Afghanistan, American options for engagement open up significantly. However, given the amount of war fatigue among the American public, it would likely have to take a direct attack against the United States or American interest to draw American into a full-scale attack against Hezbollah. Despite this, the United States may be enticed to assist Israel on some logistical level in the event of renewed hostilities, especially if there is indication that Iran ordered Hezbollah to initiate hostilities. 


\section{Lebanon}

Lebanon will host any new conflict between Israel and Hezbollah. The nation certainly warrants analysis for this predictive study. However, Lebanon, as defined by this study is not necessarily the borders of the state, or the entirety of the government, but rather the ruling coalition of the government, the March 14 Alliance and other parties that are not aligned with Hezbollah. Hezbollah is a member of the Lebanese government, and as such, would ostensibly be part of any analysis of the Lebanese government as a whole. Despite their presence in the government, Hezbollah does not act in concert or with even tacit approval of the Lebanese government. The decision-making processes of the two groups differ widely and each answer to a considerably different constituency with Hezbollah answering primarily to Shias and Iran, and the government to a wide cross-section of Lebanese society as a whole. Simply analyzing the March 14 Alliance alone is not sufficient for the study, because the decision-making process of the government vis-à-vis Hezbollah is also made in concert with parties not aligned with the Alliance. For the purposes of this study, Lebanon includes the parts of the Lebanese government that include the March 14 Alliance, parties that are non-aligned with the March 8 Coalition, and the Lebanese public as a whole.

This group is a valid choice for this analysis because their perceptions and decisions will have a profound impact on Hezbollah's decision-making. Though Hezbollah is arguably the most powerful party within Lebanon, the group cannot ignore the aggregate voice and will of the various cross-sections of Lebanese society and aspire to retain wide support. Hezbollah demonstrated their consideration for the wider Lebanese opinion in the weeks and months following the 2006 war by implementing an 
intense media campaign promoting their case for retaining arms and promoting their promise to aid in the rebuilding and recovery efforts in the country. Lebanon plays a significant part in Hezbollah's decision-making process and is certainly worth studying and understanding for this analysis.

\section{Economic}

Lebanon's economy has faced significant obstacles in recent years. After a steady recovery following the end of the civil war in 1990, the Lebanese economy was dealt a severe blow by the 2006 war between Israel and Hezbollah. The IAF followed through on Halutz's promise to set Lebanon back twenty years through an extensive bombing campaign that targeted key parts of Lebanese infrastructure (BBC News A 2006). The economy has yet to fully recover from the devastation of the war, due to the slow timetable and high cost of recovery and rebuilding, despite Hezbollah's efforts to foot some of the bill.

Lebanon is considered a significant financial center in the Middle East even with the recent turmoil within the country. However, yet another war between Hezbollah and Israel could prove very devastating to Lebanon's recovery efforts, and the Lebanese government has tried to take steps to ensure that it is complying with UN Resolution 1701 with as much vigor as the government can politically afford. The fragile state of the Lebanese economy has put avoidance of a new war between Hezbollah and Israel as a key goal for the Lebanese government. The degree to which the Lebanese government can influence Hezbollah is not significant, except through appealing to the Lebanese people about the dangers of a new war on the state of the national economy.

\section{Political}


Lebanon is governed according to the provisions of the Taif Agreement. The Taif Agreement is the result of a compromise following the civil war between Lebanon's major religious groups, the Christian, Sunni Muslims, and Shia Muslims that divided government authority in a way that was more proportional to the population of each group. However, the proportions represented in the government still retain as its foundation a census taken in 1932 (United Nations). No census has been taken in the intervening years, amid Christian fears that they will lose the high percentage of the share in power that they currently enjoy. The CIA estimates that the Shias are the largest faith group in Lebanon (Central Intelligence Agency). Hezbollah and the Amal Movement have been pushing for Shia power in proportion to their population, but have faced significant opposition in Beirut.

From 1975 through 2005, Syrian troops and intelligence officers were a significant presence in Lebanon, and significantly influenced Lebanese politics. Lebanese resentment over Syrian interference grew until, after Hariri's assassination, it reached a fevered pitch. The killing was blamed on Syria, who maintained innocence. Nevertheless, Lebanese citizens turned out for massive protests that resulted in the Syrian government deciding to pull its troops and intelligence agents out of Lebanon in 2005. This watershed event is now known as the Cedar Revolution and the political bloc that formed from this event is known as the March 14 Alliance, a reference to the date of the protest.

Though Syria pulled out of Lebanon in 2005, accusations of Syrian interference in Lebanon continued. The 2007 assassination of Pierre Gemayel was widely attributed to Syria or Syrian-aligned elements in Lebanon. The March 8 Coalition formed in 
opposition to the March 14 Alliance, and supported a greater role for Syria within Lebanon. Hezbollah is a leading member of this Coalition.

Lebanon recently enjoyed the second general elections held since the Syrian withdrawal from the country. Despite losing the popular vote to the March 8 Coalition, the Western-leaning March 14 Alliance obtained the majority of seats in the Parliament, which has been perceived as a victory among their supporters within Lebanon and in Western circles. The victory rings hollow as the March 8 Coalition proved that it has wide support from the Lebanese public, giving Hezbollah greater leverage against the Lebanese government.

Politically, the Lebanese government has a legal advantage over Hezbollah. This is not altogether insignificant, since Hezbollah has demonstrated willingness to work within the Lebanese legal framework to achieve its goals. However, Hezbollah wields the power that comes with the support of the Lebanese public. The March 14 Alliance can claim the majority of seats in Parliament, but cannot claim a mandate from the Lebanese people. The Lebanese government has limited political options to reign in Hezbollah in the event that the government feels threatened by Hezbollah's provocative behavior toward Israel.

\section{Security}

The Lebanese army is notoriously anemic. The army still suffers from internal division along sectarian lines, and an attempt by the government to use the army to quell a Lebanese militia could cause a great deal of dissention among the ranks of soldiers in the military. Without a mandate, or even unity within its own ranks, the Lebanese armed forces lack the political capacity to maintain peace among various Lebanese militias. 
Compounding the problem presented by sectarian divide is the paucity of modern military equipment. The Lebanese military lacks an effective air force, relying on helicopters to provide limited support for its ground forces (Lebanese Air Force). The Lebanese Navy is also ineffective, with limited equipment and training. Lebanese armor is limited to second-generation MBTs such as the M60 Patton (Defense News 2008). Lebanon is currently in negotiations with Russia to obtain the advanced T-90 MBT, but no deals have been concluded as of July 2009 (An-Nahar 2008).

The Lebanese are impotent against not only the IDF, but even Hezbollah and other Lebanese militias. The army fought a protracted war with the Palestinian Fatah-alIslam in May 2007, which was poorly conducted, but resulted in a Pyrrhic victory for the Lebanese military (YaLibnan 2007). In May 2008 clashes between Hezbollah and the government, the army proved unwilling and unable to confront the group, instead acting as an executor of Hezbollah's will in restoring the group's communications that had been shut down by the government (France 24 2008).

The Lebanese army has a limited presence in southern Lebanon. The army mandate in southern Lebanon is semi-officially supplanted by the UNFIL mandate as part of UN Resolution 1701, and unofficially by a rejuvenated Hezbollah presence in the region. The army did not play a role in confronting Israel during the war in 2006, and is not likely to confront Israel in the case of a new war. Meanwhile, the military has limited capability to suppress Hezbollah and demonstrated no willingness to attempt such engagement of the group.

The leverage that the Lebanese government holds over Hezbollah is legal and moral in nature. If Hezbollah wishes to make inroads into the Lebanese government 
through legal means, the group will have to submit to legal authority, even if only as a pretense. While the government does have a standing army that has a larger number of soldiers than Hezbollah, the military is poorly equipped, of divided loyalty, and of low morale. The military cannot be trusted or used to confront Hezbollah militarily, and any attempt by the Lebanese government to do so could likely trigger a new civil war.

\section{Possible Courses of Action}

Each actor can have a significant impact on the prospects for war between Hezbollah and Israel. The next part of the LAMP method is to determine all possible courses of action for each actor. While there is an infinite set of possible courses of action for each actor, a deeper study of the situation reveals that there are a limited number of actions that are available to the actors in this study.

There are four possible courses of action for each actor. One of the four possible courses of action is for each party to do nothing. While this is always a possibility, it is a very low probability in this scenario. Hezbollah, by virtue of its charter and vision and by virtue of its need to maintain a pretense for its status as an armed militia, will continue to seek out avenues to engage Israel. Israel is extremely unlikely to do nothing in the face of a Hezbollah attack or provocation. Because of Hezbollah's inclination to act and Israel's inclination to react, the United States and Lebanon are extremely unlikely to do nothing in response to the continued development of a new conflict. While the latter two actors could simply ignore the growing indicators of a new war, decisions made by Israel and Hezbollah are very likely to transpose inactivity by the United States and Lebanon into activity of some kind, even if it is a condemnation issued through diplomatic 
channels. It is for these reasons that the course of inactivity was omitted from this analysis.

In an effort to make the analysis more palatable for both the analyst and for the reader, courses of action were adjusted to fit into a paradigm of three choices. The initial analysis called for five courses of action, including the option to do nothing. This made the analysis unwieldy, and courses of action were merged to create a new course of action that represents levels of response. The limited response course of action is the result of the convergence of two courses of action that were previously independent. Namely, these were represented by a limited military option and a limited covert option. Because both of these represented a limited response, these are presented in this analysis as two possibilities within the scope of limited response.

Hezbollah is the catalyst for a renewed conflict. While it is possible that Israel may take the initiative to attack Hezbollah in Lebanon, this scenario is highly unlikely. The political cost of starting a war without pretense with as powerful an enemy as Hezbollah, which can rain rockets down upon Israel with alarming frequency, would undoubtedly prove so unpopular domestically as to make the option prohibitive and politically suicidal. Moreover, the Israeli operation in 2006 was carried out in response to a Hezbollah attack and was still roundly condemned internationally and eventually domestically as the operation began to bog down. If Israel is going to war with Hezbollah, it is most likely that it will require either a strong provocation or attack of some kind from Hezbollah. It is for this reason that Hezbollah's decisions will serve as the major scenarios by which the other actors respond. 
While not all possible courses of action may necessarily make sense for each actor, it is important to consider it as a possible future in an effort to mitigate bias in the study. Considering the seemingly illogical alternative futures is an important manifestation of the divergent thinking that is required to ensure that the study has considered all possibilities, even if they may be dismissed on logical grounds.

It is noteworthy that each actor according its capabilities and perceptions manifests each possible course of action differently. The manner in which the United States would execute a full assault is drastically different from the manner in which the Lebanese government would undertake the same course of action. In light of this, clarifications on what each course of action entails for each actor will be included in the analysis.

\section{Diplomatic Engagement}

\section{Israel}

Israeli diplomatic engagement of Hezbollah would not be direct because Israel will not negotiate with the group, nor will Hezbollah negotiate with Israel. Rather, Israeli options for diplomatic engagement would take the form of either condemnations, threats issued against Hezbollah in the media, or against Lebanon on the pretext that Lebanon holds ultimate responsibility for the actions of one of its member parties. Depending on the circumstances, Israel may offer an arbitration option through a third-party to negotiate. Because Israel has no official relations with Lebanon and does not trade with the nation, the option of political or economic sanctions is moot. Israel could choose to lobby a formal complaint with the United Nations. Lastly, Israel could mass troops near the Lebanese border in an effort to intimidate Hezbollah or the Lebanese government. 


\section{United States}

The United States wields considerable diplomatic power in the Middle East. The United States has the option to pursue diplomatic sanctions against the Lebanese government, or economic sanctions in a bid to pressure the Lebanese government to take a harder line with Hezbollah. The United States, as a permanent member of the UN Security Council, wields influence within the United Nations and may choose to pursue other legal actions against Lebanon. The United States can also choose to condemn Hezbollah for its actions. The United States could choose to deploy a carrier group into the eastern Mediterranean in a show of force to intimidate Hezbollah or the Lebanese government.

\section{Lebanon}

The Lebanese government has limited options for diplomatic engagement. The government can issue a condemnation of Hezbollah's actions on the pretense that their actions recklessly endanger the territorial and economic integrity of the nation. The government could choose to withhold or otherwise restrict Hezbollah's legislative ability in the Parliament, but risks raising the stakes in the situation by doing so.

\section{Limited Response}

\section{Israel}

This course of action affords Israel a great deal of flexibility in their response to Hezbollah's actions. Israel's options in a limited response include a singular or small amount of bombing missions against key Hezbollah targets within Lebanon. Israel could embark on a targeted killing campaign, targeting top Hezbollah political or military leaders. Israel could likewise opt for a special forces raid into Lebanon to either kill or 
abduct key members of Hezbollah's leadership. Israel could focus its intelligence operations capabilities on attempting to kill or abduct Hezbollah agents and operatives outside the Middle East.

\section{United States}

The United States can either offer logistical support for Israeli action, or logistical and moral support for wider Lebanese action. The United States could choose to bomb key Hezbollah targets within Lebanon, or provide assistance to the Israeli military in blocking Iranian attempts to ship or transport arms to Hezbollah. The United States could choose to turn its counter-terror operations focus toward Hezbollah, pursuing Hezbollah operatives not only in Lebanon, but elsewhere around the world.

\section{Lebanon}

The Lebanese government has limited options for this course of action. The government could choose to conduct covert operations against Hezbollah leadership, particularly in the form of assassinations of Hezbollah leadership. The government may opt to cut Hezbollah's communications in Beirut again, but run the risk of repeating the unrest of May 2008. The government could also take the risky action of logistically supporting an Israeli or American action against Hezbollah.

\section{Full Assault}

\section{Israel}

A full assault from Israel entails a comprehensive bombing campaign and eventual ground invasion of Lebanon, in conjunction with a blockade around Lebanon.

\section{United States}


An American full assault would entail an extensive bombing campaign and a possible deployment of American troops within Lebanon. The extent of the deployment would be subject to the status of American operations in Iraq and Afghanistan.

\section{Lebanon}

A full assault would entail an attempt by the Lebanese army to push Hezbollah's military wing from strategic footholds in Lebanon, such as the Bekaa Valley, South Beirut, and southern Lebanon. The government may also choose to expel Hezbollah from the Lebanese Parliament, though the legality of such a move is highly questionable.

\section{Major Scenarios}

For the purposes of this study, the actions of Hezbollah will serve as the baseline and provide the major scenarios according to which the other actors will respond with one of the three courses of action elucidated above. The fourth option of inaction is not applicable to this analysis. If Hezbollah were to do nothing, the level of interaction between the three nations and Hezbollah would be dramatically altered in such a way as to be irrelevant to this study.

Further, it is highly unlikely that Hezbollah would not continue its struggle with Israel. Such an idea runs counter to the organization's mission statement issued in 1988, and to the group's claims that its arms are necessary for the struggle to "liberate Palestine". Hezbollah is also motivated by the assassination of Imad Mugniyeh to seek an avenue of revenge against Israel, whom Hezbollah holds responsible for the killing. There are three courses of action that Hezbollah could pursue, producing three distinct major scenarios to which the actors will respond.

1. Hezbollah conducts terror attack against Israeli or Jewish targets outside Israel. 
2. Hezbollah launches a direct military attack against Israel.

3. Hezbollah provokes Israel to attack.

The first two scenarios require little explanation, but the third scenario requires clarification. Hezbollah's provocation of Israel could involve a variety of actions, ranging from issuing threats against Israel or the IDF, staging exercises near the Israeli border, moving troops and equipment close to the Israeli border, and even launching a very small number of Katyusha rockets across the border into Israel. The latter example would constitute an attack in the strictest sense of the word, but falls short of the premeditation and planning behind the operation that triggered the 2006 war.

\section{Calculation of Total Alternate Futures}

Each action by Hezbollah is likely to elicit a very different response from each actor. In order to predict the most probable alternate future, one must analyze all possible permutations of the actions taken by Israel, the United States, and Lebanon to each of the possible scenarios that are created by Hezbollah's decisions. The equation for calculating the total number of alternate futures in a LAMP analysis is $\mathrm{X}^{\mathrm{Y}}=\mathrm{Z}$, where $\mathrm{X}$ equals the number of actions available to each actor, $\mathrm{Y}$ equals the number of actors, and $\mathrm{Z}$ equals the total number of alternate futures to be compared (Lockwood 2008). When calculating this formula, Hezbollah's choices are not counted among the actions available, nor is the group counted among the total number of actors, since the group and its actions represent the catalyst and three scenarios respectively.

There are three possible courses of action for each actor, and three actors in the analysis, which renders the equation as $3^{3}=27$. This means that there are 27 possible futures between Israel, the United States, and Lebanon when responding to any one of the 
scenarios that results from Hezbollah's own courses of action. Each of the 27 alternate futures will be submitted to a pairwise comparison for each scenario and ranked according to the results. In an effort to render the comparison charts more easily decipherable, the following abbreviations for each course of action will be used.

1. Diplomatic Engagement (DIP)

2. Limited Response (LIM)

3. Full Assault (FUL)

Table 1: Alternate Future Permutations

\begin{tabular}{|c|c|c|c|}
\hline $\begin{array}{c}\text { Possible } \\
\text { Future } \#\end{array}$ & Israel & $\begin{array}{c}\text { United } \\
\text { States }\end{array}$ & Lebanon \\
\hline 1 & FUL & FUL & FUL \\
\hline 2 & FUL & FUL & LIM \\
\hline 3 & FUL & FUL & DIP \\
\hline 4 & FUL & LIM & FUL \\
\hline 5 & FUL & LIM & LIM \\
\hline 6 & FUL & LIM & DIP \\
\hline 7 & FUL & DIP & FUL \\
\hline 8 & FUL & DIP & LIM \\
\hline 9 & FUL & DIP & DIP \\
\hline 10 & LIM & FUL & FUL \\
\hline 11 & LIM & FUL & LIM \\
\hline 12 & LIM & FUL & DIP \\
\hline 13 & LIM & LIM & FUL \\
\hline 14 & LIM & LIM & LIM \\
\hline 15 & LIM & LIM & DIP \\
\hline 16 & LIM & DIP & FUL \\
\hline 17 & LIM & DIP & LIM \\
\hline 18 & LIM & DIP & DIP \\
\hline 19 & DIP & FUL & FUL \\
\hline 20 & DIP & FUL & LIM \\
\hline 21 & DIP & FUL & DIP \\
\hline 22 & DIP & LIM & FUL \\
\hline 23 & DIP & LIM & LIM \\
\hline 24 & DIP & LIM & DIP \\
\hline 25 & DIP & DIP & FUL \\
\hline 26 & DIP & DIP & LIM \\
\hline 27 & DIP & DIP & DIP \\
\hline
\end{tabular}




\section{Pairwise Comparison of Alternate Futures for Each Scenario}

Using Table 1 as a template, the alternate futures will be submitted to a pairwise comparison for each scenario. The method behind this type of comparison is simple and involves comparing each alternate future against each other alternate future in an effort to determine the most likely scenarios. To provide an illustration of the process, Table 1 will be utilized. Using alternate future \#1, the analyst will compare that alternate future to alternate future $\# 2$ and assign a vote to the more probable future. Then, the analyst will compare alternate future \#1 against alternate future \#3 and assign a point to the more probable scenario. Alternate future \#1 will be likewise compared with each of the remaining futures. Once alternate future \#1 has been compared to each other future, the analyst will start with alternate future \#2 and compare to alternate future \#3, since futures $\# 1$ and \#2 have already been compared. Alternate future \#2 will be compared with each other future until it has been compared with each future. This process will continue for each alternate future until all futures have been compared. At the end of the pairwise comparison, the more probable futures will be apparent due to the larger number of votes in relation to the other less probable futures.

The equation used to determine the total number of pairwise comparisons for each scenario is $\mathrm{X}=\mathrm{n}(\mathrm{n}-1) / 2$, where $\mathrm{n}$ equals the number of alternate futures to be analyzed and X equals the total number of pairwise comparisons for each scenario (Lockwood 2008). In the case of this analysis, the equation is rendered as $351=27(27-1) / 2$, meaning there are a total of 351 pairwise comparisons to be made for each scenario, which are represented as votes in the tables below. The following tables present the results of the pairwise comparisons of each alternate future for each scenario. 
Table 2: Alternate Futures Pairwise Comparison - Scenario 1

\begin{tabular}{|c|c|c|c|c|}
\hline \multicolumn{5}{|c|}{ Hezbollah Conducts Terror Attack } \\
\hline $\begin{array}{c}\text { Possible } \\
\text { Futures }\end{array}$ & Israel & $\begin{array}{c}\text { United } \\
\text { States }\end{array}$ & Lebanon & votes \\
\hline 1 & FUL & FUL & FUL & 6 \\
\hline 2 & FUL & FUL & LIM & 16 \\
\hline 3 & FUL & FUL & DIP & 20 \\
\hline 4 & FUL & LIM & FUL & 12 \\
\hline 5 & FUL & LIM & LIM & 18 \\
\hline 6 & FUL & LIM & DIP & 22 \\
\hline 7 & FUL & DIP & FUL & 15 \\
\hline 8 & FUL & DIP & LIM & 19 \\
\hline 9 & FUL & DIP & DIP & 25 \\
\hline 10 & LIM & FUL & FUL & 7 \\
\hline 11 & LIM & FUL & LIM & 13 \\
\hline 12 & LIM & FUL & DIP & 15 \\
\hline 13 & UIM & LIM & FUL & 4 \\
\hline 14 & LIM & LIM & LIM & 19 \\
\hline 15 & LIM & LIM & DIP & 24 \\
\hline 16 & LIM & DIP & FUL & 2 \\
\hline 17 & LIM & DIP & LIM & 16 \\
\hline 18 & LIM & DIP & DIP & 26 \\
\hline 19 & DIP & FUL & FUL & 3 \\
\hline 20 & DIP & FUL & LIM & 6 \\
\hline 21 & DIP & FUL & DIP & 7 \\
\hline 22 & DIP & LIM & FUL & 2 \\
\hline 23 & DIP & LIM & LIM & 11 \\
\hline 24 & DIP & LIM & DIP & 11 \\
\hline 25 & DIP & DIP & FUL & \\
\hline 26 & DIP & DIP & LIM & 9 \\
\hline 27 & DIP & DIP & DIP & 23 \\
\hline & & & Total & 351 \\
\hline
\end{tabular}


Table 3: Alternate Futures Pairwise Comparison - Scenario 2

\begin{tabular}{|c|c|c|c|c|}
\hline \multicolumn{5}{|c|}{ Hezbollah Military Attack on Israel } \\
\hline $\begin{array}{c}\text { Possible } \\
\text { Futures }\end{array}$ & Israel & $\begin{array}{c}\text { United } \\
\text { States }\end{array}$ & Lebanon & Votes \\
\hline 1 & FUL & FUL & FUL & 15 \\
\hline 2 & FUL & FUL & LIM & 20 \\
\hline 3 & FUL & FUL & DIP & 22 \\
\hline 4 & FUL & LIM & FUL & 16 \\
\hline 5 & FUL & LIM & LIM & 20 \\
\hline 6 & FUL & LIM & DIP & 23 \\
\hline 7 & FUL & DIP & FUL & 15 \\
\hline 8 & FUL & DIP & LIM & 24 \\
\hline 9 & FUL & DIP & DIP & 26 \\
\hline 10 & LIM & FUL & FUL & 2 \\
\hline 11 & LIM & FUL & LIM & 10 \\
\hline 12 & LIM & FUL & DIP & 12 \\
\hline 13 & LIM & LIM & FUL & 9 \\
\hline 14 & LIM & LIM & LIM & 15 \\
\hline 15 & LIM & LIM & DIP & 20 \\
\hline 16 & LIM & DIP & FUL & 7 \\
\hline 17 & LIM & DIP & LIM & 19 \\
\hline 18 & LIM & DIP & DIP & 24 \\
\hline 19 & DIP & FUL & FUL & 4 \\
\hline 20 & DIP & FUL & LIM & 5 \\
\hline 21 & DIP & FUL & DIP & 6 \\
\hline 22 & DIP & LIM & FUL & 3 \\
\hline 23 & DIP & LIM & LIM & 7 \\
\hline 24 & DIP & LIM & DIP & 8 \\
\hline 25 & DIP & DIP & FUL & 1 \\
\hline 26 & DIP & DIP & LIM & 3 \\
\hline 27 & DIP & DIP & DIP & 15 \\
\hline & & & Total & 351 \\
\hline
\end{tabular}


Table 4: Alternate Futures Pairwise Comparison - Scenario 3

\begin{tabular}{|c|c|c|c|c|}
\hline \multicolumn{5}{|c|}{ Hezbollah Provokes Israel } \\
\hline $\begin{array}{l}\text { Possible } \\
\text { Futures }\end{array}$ & Israel & $\begin{array}{l}\text { United } \\
\text { States }\end{array}$ & Lebanon & Votes \\
\hline 1 & FUL & FUL & FUL & 8 \\
\hline 2 & FUL & FUL & LIM & 11 \\
\hline 3 & FUL & FUL & DIP & 19 \\
\hline 4 & FUL & LIM & FUL & 8 \\
\hline 5 & FUL & LIM & LIM & 12 \\
\hline 6 & FUL & LIM & DIP & 20 \\
\hline 7 & FUL & DIP & FUL & 12 \\
\hline 8 & FUL & DIP & LIM & 18 \\
\hline 9 & FUL & DIP & DIP & 23 \\
\hline 10 & LIM & FUL & FUL & 6 \\
\hline 11 & LIM & FUL & LIM & 12 \\
\hline 12 & LIM & FUL & DIP & 15 \\
\hline 13 & LIM & LIM & FUL & 3 \\
\hline 14 & LIM & LIM & LIM & 16 \\
\hline 15 & LIM & UM & DIP & 24 \\
\hline 16 & LIM & DIP & FUL & 4 \\
\hline 17 & LIM & DIP & LIM & 20 \\
\hline 18 & LIM & DIP & DIP & 25 \\
\hline 19 & DIP & FUL & FUL & 1 \\
\hline 20 & DIP & FUL & LIM & 8 \\
\hline 21 & DIP & FUL & DIP & 10 \\
\hline 22 & DIP & LIM & FUL & 2 \\
\hline 23 & DIP & LIM & LIM & 12 \\
\hline 24 & DIP & LIM & DIP & 16 \\
\hline 25 & DIP & DIP & FUL & 2 \\
\hline 26 & DIP & DIP & LIM & 18 \\
\hline \multirow[t]{2}{*}{27} & DIP & DIP & DIP & 26 \\
\hline & & & Total & 351 \\
\hline
\end{tabular}

\section{Ranking the Alternate Futures}

Using the results from Tables 2, 3 and 4, the futures for each scenario will be ranked in order of probability with the highest probability futures at the top and the lowest probability futures at the bottom. The following tables illustrate the ranked pairwise comparison of alternate futures for each scenario. 
Table 5: Alternate Future Probabilities By Rank - Scenario 1

\begin{tabular}{|c|c|c|c|c|}
\hline \multicolumn{5}{|c|}{ Hezbollah Conducts Terror Attack } \\
\hline $\begin{array}{c}\text { Possible } \\
\text { Futures }\end{array}$ & Israel & $\begin{array}{c}\text { United } \\
\text { States }\end{array}$ & Lebanon & votes \\
\hline 18 & LIM & DIP & DIP & 26 \\
\hline 9 & FUL & DIP & DIP & 25 \\
\hline 15 & LIM & LIM & DIP & 24 \\
\hline 27 & DIP & DIP & DIP & 23 \\
\hline 6 & FUL & LIM & DIP & 22 \\
\hline 3 & FUL & FUL & DIP & 20 \\
\hline 8 & FUL & DIP & LIM & 19 \\
\hline 14 & LIM & LIM & LIM & 19 \\
\hline 5 & FUL & LIM & LIM & 18 \\
\hline 2 & FUL & FUL & LIM & 16 \\
\hline 17 & LIM & DIP & LIM & 16 \\
\hline 7 & FUL & DIP & FUL & 15 \\
\hline 12 & IIM & FUL & DIP & 15 \\
\hline 11 & LIM & FUL & LIM & 13 \\
\hline 4 & FUL & LIM & FUL & 12 \\
\hline 23 & DIP & LIM & LIM & 11 \\
\hline 24 & DIP & LIM & DIP & 11 \\
\hline 26 & DIP & DIP & LIM & 9 \\
\hline 10 & LIM & FUL & FUL & 7 \\
\hline 21 & DIP & FUL & DIP & 7 \\
\hline 1 & FUL & FUL & FUL & 6 \\
\hline 20 & DIP & FUL & LIM & 6 \\
\hline 13 & LIM & LIM & FUL & 4 \\
\hline 19 & DIP & FUL & FUL & 3 \\
\hline 16 & LIM & DIP & FUL & 2 \\
\hline 25 & DIP & LIM & FUL & 2 \\
\hline & DIP & DIP & FUL & 0 \\
\hline & & & Total & 351 \\
\hline
\end{tabular}


Table 6: Alternate Future Probabilities By Rank - Scenario 2

\begin{tabular}{|c|c|c|c|c|}
\hline \multicolumn{5}{|c|}{ Hezbollah Military Attack on Israel } \\
\hline $\begin{array}{c}\text { Possible } \\
\text { Futures }\end{array}$ & Israel & $\begin{array}{c}\text { United } \\
\text { States }\end{array}$ & Lebanon & Votes \\
\hline 9 & FUL & DIP & DIP & 26 \\
\hline 8 & FUL & DIP & LIM & 24 \\
\hline 18 & LIM & DIP & DIP & 24 \\
\hline 6 & FUL & LIM & DIP & 23 \\
\hline 3 & FUL & FUL & DIP & 22 \\
\hline 2 & FUL & FUL & LIM & 20 \\
\hline 5 & FUL & LIM & LIM & 20 \\
\hline 15 & LIM & LIM & DIP & 20 \\
\hline 17 & LIM & DIP & LIM & 19 \\
\hline 4 & FUL & LIM & FUL & 16 \\
\hline 1 & FUL & FUL & FUL & 15 \\
\hline 7 & FUL & DIP & FUL & 15 \\
\hline 14 & LIM & LIM & LIM & 15 \\
\hline 27 & DIP & DIP & DIP & 15 \\
\hline 12 & LIM & FUL & DIP & 12 \\
\hline 11 & LIM & FUL & LIM & 10 \\
\hline 13 & LIM & LIM & FUL & 9 \\
\hline 24 & DIP & LIM & DIP & 8 \\
\hline 16 & LIM & DIP & FUL & 7 \\
\hline 23 & DIP & LIM & LIM & 7 \\
\hline 21 & DIP & FUL & DIP & 6 \\
\hline 20 & DIP & FUL & LIM & 5 \\
\hline 19 & DIP & FUL & FUL & 4 \\
\hline 22 & DIP & LIM & FUL & 3 \\
\hline 26 & DIP & DIP & LIM & 3 \\
\hline 10 & LIM & FUL & FUL & 2 \\
\hline 25 & DIP & DIP & FUL & 1 \\
\hline & & & Total & 351 \\
\hline
\end{tabular}


Table 7: Alternate Future Probabilities By Rank - Scenario 3

\begin{tabular}{|c|c|c|c|c|}
\hline \multicolumn{5}{|c|}{ Hezbollah Provokes Israel } \\
\hline $\begin{array}{c}\text { Possible } \\
\text { Futures }\end{array}$ & Israel & $\begin{array}{c}\text { United } \\
\text { States }\end{array}$ & Lebanon & Votes \\
\hline 27 & DIP & DIP & DIP & 26 \\
\hline 18 & LIM & DIP & DIP & 25 \\
\hline 15 & LIM & LIM & DIP & 24 \\
\hline 9 & FUL & DIP & DIP & 23 \\
\hline 6 & FUL & LIM & DIP & 20 \\
\hline 17 & LIM & DIP & LIM & 20 \\
\hline 3 & FUL & FUL & DIP & 19 \\
\hline 8 & FUL & DIP & LIM & 18 \\
\hline 26 & DIP & DIP & LIM & 18 \\
\hline 14 & LIM & LIM & LIM & 16 \\
\hline 24 & DIP & LIM & DIP & 16 \\
\hline 12 & LIM & FUL & DIP & 15 \\
\hline 5 & FUL & LIM & LIM & 12 \\
\hline 7 & FUL & DIP & FUL & 12 \\
\hline 11 & LIM & FUL & LIM & 12 \\
\hline 23 & DIP & LIM & LIM & 12 \\
\hline 2 & FUL & FUL & LIM & 11 \\
\hline 21 & DIP & FUL & DIP & 10 \\
\hline 1 & FUL & FUL & FUL & 8 \\
\hline 4 & FUL & LIM & FUL & 8 \\
\hline 20 & DIP & FUL & LIM & 8 \\
\hline 10 & LIM & FUL & FUL & 6 \\
\hline 16 & LIM & DIP & FUL & 4 \\
\hline 13 & LIM & LIM & FUL & 3 \\
\hline 22 & DIP & LIM & FUL & 2 \\
\hline 19 & DIP & DIP & FUL & 2 \\
\hline & DIP & FUL & FUL & 1 \\
\hline & & Total & 351 \\
\hline
\end{tabular}

\section{Analysis of Alternate Futures}

Tables 5, 6, and 7 show a clear demarcation in the behavior patterns of Israel and the United States in response to Hezbollah's decisions. The next part of the LAMP method calls for an analysis of the alternate futures within each scenario, how these futures will affect Hezbollah's decision-making process, and a prediction of how these alternate futures will affect each scenario. In order to make this analysis more concise, 
palatable, and relevant for the reader, only the five most likely futures in each scenario will be analyzed.

\section{Scenario 1 - Hezbollah Terror Attack Against Israeli or Jewish Target Abroad}

In this scenario, Hezbollah will choose to conduct an attack against an Israeli or Jewish target in a country other than Israel. The potential targets are varied. Israeli embassies, Jewish recreation centers, synagogues, and other places where Israelis or Jews may congregate are all possibilities for targeting by Hezbollah. Hezbollah has shown willingness to conduct attacks against "soft targets" like these in the past, most notably in 1992 and 1994 when the group allegedly carried out a series of bombings against Jewish targets in Argentina. Recently, Azerbaijani counter-terror efforts uncovered a Hezbollah plot to bomb a Jewish center in Baku, Azerbaijan.

While the targeting of Hezbollah attacks may appear random to the casual observer, there are two distinct characteristics that Baku and Buenos Aires share. They are both significant areas of Jewish populations, and are located in countries that lack the willingness or capacity to strike Hezbollah in retaliation for the attacks. Both of these characteristics are advantageous to Hezbollah. It ensures a higher number of casualties and provides Hezbollah with reasonable assurance that the group will not have to suffer existential consequences as a result of the attack. Assuming that these two factors are of high importance to the group in planning an attack, certain sites that don't meet one of the criteria can be regarded as having a diminished threat.

International outcry would likely follow after a successful Hezbollah attack, and it is highly likely that the group would go to some length to conceal its involvement. Because of Hezbollah's call for revenge in the death of Imad Mugniyeh, any 
sophisticated terror attack against a Jewish target would be potentially regarded in Jerusalem as a Hezbollah operation, and blame would be fixed accordingly. American reaction to the attack would depend on the scope of the attack and the location of the attack. An attack in a Western allied city would likely draw stronger condemnation than an attack in a city that lay in a non-aligned nation. In the case of a Hezbollah terror attack, the group runs the risk of inviting a wide international response of some kind and could potentially throw the Middle East into a perilous state of instability.

Alternate Future \#18: Israel conducts a limited response to the terror attack, while the United States and Lebanon choose to handle the situation through diplomatic channels.

This future received 26 votes, making it the most likely future to occur within this scenario. This future has played out with frequency over the course of Israeli history, as Israeli responses to terror attacks within Israel tend to focus on small attacks and assassination attempts. Israel did not immediately retaliate for the pair of bombings that occurred in Argentina during the early 1990s, but the Mossad has been blamed for the assassination of Imad Mugniyeh, named by the Argentine government as the architect of two bombings (Norton 2007, 79).

In this future, Israel pursues a targeted killing strategy and assassinates a ranking member of Hezbollah. Between the options of a limited military strike or an assassination, the former is less likely to elicit a response from Hezbollah, but is also likely to have less impact on Hezbollah's operations. Hezbollah would likely be prepared for the eventuality of a limited military strike and would take precautions to ensure that any exposed targets are clear of key Hezbollah leaders or equipment before the execution 
of the terror attack. An Israeli attack on these "empty targets" would be a best-case scenario for Hezbollah, who would lose little in such an attack.

If an Israeli strike on empty targets represents a best-case scenario, the assassination of a key member of Hezbollah's leadership might be a worst-case scenario for the group. Israel's targeted killing strategy has proven rather effective at reaching key leaders of the targeted groups. Israel has proven that it has the capabilities to carry out such attacks through its successful operations against Hamas leaders such as Abdel Aziz al-Rantisi and founder Ahmed Yassin, as well as Hezbollah leaders Imad Mugniyeh and Sayed Abbas al-Musawi. However, such actions introduce greater instability and the danger that the situation could spiral further out of control. Hezbollah would be highly unlikely to permit such an attack to go unanswered. The potential for the conflict to grow in its scope could increase significantly in the event of a successful Israeli operation to assassinate a member of Hezbollah's leadership.

In this future, the American and Lebanese responses would be diplomatic in nature. The United States issues a statement condemning the attack. The strength of the language in such a statement will depend on the degree to which Hezbollah culpability could be proven. The higher the likelihood of Hezbollah involvement, the more likely the United States would be to issue a strongly worded statement against the action. The United States looks the other way in the case of a limited response from Israel, only urging caution in the event that Israel's actions appear to further destabilize the region.

The Lebanese government issues a condemnation of the attack, but it is not strongly worded. Public statements from Lebanon would extol the virtues of dialogue. 
However, in private, the Lebanese government communicates with Hezbollah its concerns that Hezbollah's actions could threaten the national security of Lebanon.

Alternate Future \#9: Israel launches a full military assault against Hezbollah, while the United States and Lebanon choose to handle the situation through diplomatic channels.

In this scenario, this alternate future received 25 votes, meaning that this future is the second most likely future compared to the other alternate futures. This future has been made more likely with the election of the hawkish Likud party in February 2009. This future represents a significant escalation of the conflict between Israel and Hezbollah.

In this future, Israel attacks Hezbollah with the full might of the IDF. The reasoning behind such an undertaking by Israel in this future is to further bolster its strategic deterrence against Hezbollah. This reaction has precedent in Israeli history, dating to the 1982 invasion of Lebanon that was launched after the attempted assassination of Shlomo Argov (The Guardian 2003).

The operation begins in the same manner as the 2006 war, with a full compliment of IAF sorties over Lebanon in an effort to destroy key points in the Lebanese and Hezbollah infrastructure. Unlike 2006, the ground invasion is undertaken sooner in the campaign and more forcefully, with clear objectives from the IDF Chief of Staff Gabi Ashkenazi.

Hezbollah's response to this invasion mirrors the group's response in 2006, with a regular volley of Katyusha rockets being fired into Israel. The IDF's ability to limit or halt these attacks altogether will be a major determining factor in both the length of the war and perceptions of the IDF's performance. In this future, the IDF is unable to stem 
the flow of Katyushas falling on Israel, and the army is forced to quit the operation early due to a jaded Israeli public.

The war results in a diminished military capability for Hezbollah. However, the group retains popularity among the Lebanese most affected by the Israeli operation, and more importantly, bolsters its case for retaining its arms. The war increases Israel's deterrence posture against Hezbollah and quells Hezbollah's appetite to engage Israel so blatantly in the future.

The American response to the terror attack is to issue a condemnation, the language of which would be catered to the situation. If Hezbollah's culpability were proven, the language of an American condemnation would be markedly stronger. The American response to the Israeli invasion of Lebanon is ambivalent. The United States urges Israel to show restraint, and there are calls from within the Senate and House to issue a condemnation of Israel's escalation, citing Israel for its "disproportionate response" to the terror attack. While the Obama administration does not heed those calls, such sentiment prompts the administration to take a tougher line with Israel and pressure the nation to recall its forces from Lebanon.

The Lebanese government issues a thinly worded condemnation of the Hezbollah attacks at the outset. However, as Israeli aircraft begin flying sorties over Lebanon and Israeli tanks cross into the south, the government becomes inclined to chide Hezbollah for its reckless behavior, while condemning Israel for its "disproportionate response". The government complains to the United Nations and pushes for a condemnation from the UN Security Council, which does not pass unanimously due to the United States. However, the United Nations begins to put pressure on Israel as the operation begins to 
move beyond the first week. The Lebanese government issues warnings to the Israeli government that the Lebanese army may be used to engage the IDF if the latter pushes too far into Lebanon.

Alternate Future \#15: Israel and the United States pursue a limited response to the terror attack, while Lebanon chooses to handle the situation through diplomatic channels.

This future received 24 votes and is the third most likely future to occur in this scenario. This future represents a major departure from the two more probable scenarios in that the United States is taking a more active role against Hezbollah. Lebanon, unsurprisingly, retains the use of diplomatic channels to engage Hezbollah.

In this future, Israel has the option to pursue either the option of a limited military strike or an assassination attempt against a key member of Hezbollah's leadership. The latter could further destabilize the region, while the former is unlikely to seriously affect Hezbollah. Israel's inclination in recent years has been to pursue targeted killing campaigns against hostile non-state entities, as has been demonstrated with Israel's assassinations of key leaders in both Hamas in Hezbollah. Thus, Israel elects to assassinate a key member of Hezbollah's leadership.

The United States, in this future, pursues the option of a limited response. However, unlike Israel, the options that the United States pursues in this future are less overt and with the avoidance of international condemnation in mind. The United States takes a two-pronged approach in this future that entails logistical support for Israeli action against Hezbollah, and a boost to counter-terror efforts against Hezbollah around the world as part of the general American strategy against global terrorism. Both of these 
options afford the United States the ability to engage Hezbollah that is below the surface, less likely to be reported in the media, and still effective in engaging Hezbollah.

Hezbollah's response to these actions by the United States and Israel depends on two factors; the degree to which the action is successful against Hezbollah, and whether or not Hezbollah is able to detect American assistance to Israel. Because the action is successful, Hezbollah becomes inclined to respond with either another terror attack or may choose to escalate the conflict by striking Israel directly. If Hezbollah detects American assistance to Israel, Hezbollah may exercise options it has to confront the United States. These include targeting American troops in Iraq and conducting terror attacks on American interests abroad or perhaps even within the continental United States.

The Lebanese government's response is very similar to the response in alternate future \#18. While the Lebanese government perceives Israeli action against Hezbollah, American involvement remains outside the view of the Lebanese government.

Alternate Future \#27: Israel, the United States, and Lebanon all pursue diplomatic options to respond to Hezbollah's terror attack.

This future received 23 votes and is the fourth most likely future to occur in this scenario. This future is perhaps the most beneficial to prospects for peace in the Middle East, due primarily to Israel's decision to eschew a forceful response in deference to a diplomatic and peaceful alternative. Despite this fact, there are three futures that are more likely to occur than this one.

In this future, Israel issues a strongly worded condemnation of the attack. The government feels compelled to put the IDF on high alert in an effort to demonstrate the 
degree to which Israel is displeased with the attack and in an effort to intimidate Hezbollah. Israel issues threats to attack Hezbollah targets or even Lebanese targets in an effort to pressure Beirut to either likewise condemn Hezbollah or work harder to reign in the group. Israel pursues this option in a bid to demonstrate to the United States and the wider global community that it is dedicated to peace, even in the face of concerted provocation.

The United States issues a condemnation of the attack, the language of which is determined by the degree to which Hezbollah is found culpable for the attack. The Obama administration lauds Israel for its restraint and encourages further restraint in its dealings with Hezbollah and likewise with Hamas and other Palestinian factions. This is coupled with a warning to the Lebanese government that unless the government takes steps to put pressure on Hezbollah, the risk of escalation in the region runs high. The United States sends signals to all parties in the Middle East that while it supports Israel's restraint in this scenario, that it is less apt to do so if Israel is further provoked.

The Lebanese government issues a condemnation for the attack and behaves similarly to the way it might in alternate futures \#18 and \#15. In private, the government expresses to Hezbollah that the nation is fortunate that Israel did not respond more forcefully and encourages Hezbollah to refrain from such continued provocation.

While such a future portends a more peaceful Middle East, it is also a best-case scenario for Hezbollah. The group is unlikely to be moved by condemnations or even troop buildups within Israel. The lack of response will be perceived by Hezbollah as a victory against Israel, which the group perceives as having a weakening resolve. This development may open doors to further Hezbollah aggression. 
Alternate Future \#6: Israel launches a full assault against Hezbollah in response to the terror attack, while the United States pursues a limited response, and Lebanon pursues diplomatic channels to address the situation.

This future received 22 votes and is the fifth most likely future within this scenario. The scenario represents the most intense level of response that Hezbollah is likely to receive in the wake of a terror attack according to the pairwise comparison. As such, this future is the most likely among the five most probable futures to destabilize the region.

In this future, Israel launches a full assault that resembles that of alternate scenario \#9 almost exactly. The key change in this scenario is that Israel's response would be in concert with a limited American response. In this future, the United States lends Israel overt logistical support for its war against Hezbollah under the pretense that this war is an extension of the global strategy against Islamist terrorism. The logistical support takes the form of the sharing of intelligence on Hezbollah's movements and American support in crimping Hezbollah's supply line of weapons and resources from Iran. The United States Navy is deployed to the eastern Mediterranean to assist in an Israeli blockade of Lebanon, under the pretense of cutting off a source of Hezbollah's weapons.

The United States goes to some length to assure the Lebanese government that its actions are aimed only at confronting Hezbollah. To this end, the United States takes steps to discourage Israeli targeting of Lebanese civilian infrastructure and encourages an easing of the blockade to allow all vessels after a search to ensure that no weapons are aboard. 
In this future, the Lebanese government issues a stronger condemnation of the attacks, though still weak in comparison to condemnations from other nations. The Lebanese government privately expresses extreme displeasure with Hezbollah for provoking not only a full Israeli assault, but also American assistance. Meanwhile, the government publicly condemns the Israeli aggression and "disproportionate response", while calling on the United States to halt its assistance and complicity in the unwarranted aggression. The United States counters that its only mission is to confront Hezbollah, and that it would strive to preserve Lebanese territorial integrity to the extent possible under the circumstances.

Hezbollah's reaction to this response is to express surprise that a terror attack could warrant such a response. This would no doubt be an attempt by Hezbollah to obtain sympathy and perhaps even establish a moral high ground by citing "disproportionate response". As the United States proves unrelenting in its material support for the Israeli invasion, Hezbollah looks to frame the conflict as a clash of civilizations, and evokes the imagery of the Crusades in an attempt to rally the Arab street to its banner. The diplomatic pressure created by such a strategy tempers American support for the mission, and further destabilizes the Middle East, while threatening remaining American troops in Iraq.

The war results in a diminished military capability for Hezbollah. However, the group retains popularity among the Lebanese most affected by the Israeli operation, and more importantly, bolsters its case for retaining its arms. The war increases Israel's deterrence posture against Hezbollah and quells Hezbollah's appetite to engage Israel so blatantly in the future. 
In this scenario, among the five most probable futures, there is an 80-percent chance that Israel would respond violently to a Hezbollah terror attack, and a 40-percent chance that such a response would entail a full-scale Israeli invasion of Lebanon. There is a 40-pecent chance that the United States might provide some sort of response to the attack, the degree of which would be determined by the level of Israeli response. Unsurprisingly, the Lebanese government is 100-percent certain to do nothing more than issue a weak condemnation and express dissatisfaction to Hezbollah through private channels. According to the futures in this scenario, there is an incredibly high chance that a Hezbollah terror attack against an Israeli or Jewish target would elicit the type of response from Israel that could bring serious instability to the Middle East.

\section{Scenario 2 - Hezbollah Conducts Direct Military Attack Against Israel}

Scenario 2 resembles the events of July 12, 2006, when Hezbollah members crossed the border into Israel and ambushed an IDF patrol, taking IDF soldiers Eldad Regev and Ehud Goldwasser with them back to Lebanon. The even triggered a massive Israeli operation that lasted for 33 days and devastated southern Lebanon and parts of the southern suburbs of Beirut. As a result of this recent historical precedent, the reactions of Israel, the United States, and Lebanon are perhaps more easily analyzed and predicted, based not only on previous courses of action but the lessons learned from the events in 2006.

The top five most probable alternate futures for this scenario contain three alternate futures that are also present in Scenario 1. Not surprisingly, those three alternate futures represent the strongest probable responses from each of the three actors in that scenario. 
Alternate Future \#9: Israel launches a full military assault against Hezbollah, while the United States and Lebanon choose to handle the situation through diplomatic channels.

This future received 26 votes, making it the most likely of the 27 alternate futures to occur in this scenario. This future is among the five most probable futures in each of the three scenarios. This future is also identical to the situation that occurred in 2006 . This future is a prediction that if Hezbollah were to carry out another military attack directly against Israel, that Israel would respond in the same manner that it did in 2006.

In this future, Israel launches a full-scale invasion of Lebanon, starting with a heavy aerial bombing campaign, followed quickly by a ground invasion. The IDF will have learned lessons from the war in 2006 and does not make the same mistakes that the army did in the previous round of hostilities. Despite the increased efficiency and level of performance, the IDF will be unable to completely stem the rain of rockets falling on Israel, evoking memories of the 2006 conflict in the eyes of the Israeli public.

The United States will condemn Hezbollah's attack on Israel, while extolling the virtue of Israel's right to defend itself. However, as international pressure builds amid the rising civilian casualty count in Lebanon, the Obama administration will begin to change its tune, urging the IDF to wrap up its operation quickly. Israel will test the limits of American patience and support, eventually leading to calls from Washington for Israel to show restraint, with the more vociferous critics calling Israel's operation an example of "disproportionate response". The United States will also chide the Lebanese government for failing to abide by UN Resolution 1701 and disarming Hezbollah, which would be characterized as a step that could have prevented the war. 
The Lebanese government will criticize Hezbollah's decision to launch an attack against Israel, citing the grave threat that Lebanon faces in the midst of the Israeli onslaught. However, the Lebanese government will issue threats to the IDF that if the operation tarries for too long or if IDF troops push too deep into Lebanon, that it will reserve the right to defend itself by sending the Lebanese army into action.

The chief differences in this future from the scenario that played out in 2006 are two-fold. The IDF is unlikely to repeat the mistakes of 2006, and as a result, will increase the measure of deterrence that Israel enjoys in the Middle East. However, support from the Obama administration will be more tepid than it was under the Bush administration. Israel will not have the leeway to let the operation extend to the protracted 33-day length of the 2006 operation. Without such American support, Israel will feel compelled to shorten the operation, lest the political cost of the war become prohibitive.

The war will result in a diminished military capability for Hezbollah. However, the group will retain popularity among the Lebanese most affected by the Israeli operation, and more importantly, will bolster its case for retaining its arms. The war will increase Israel's deterrence posture against Hezbollah and likely quell Hezbollah's appetite to engage Israel so blatantly in the future.

Alternative Future \#8: Israel launches a full-scale invasion of Lebanon, the United States pursues a diplomatic option, and Lebanon pursues a limited response to Hezbollah's attack on Israel.

This future received 24 votes, tying with Alternate Future \#18 as the second most likely future in this scenario. This future and future $\# 3$ are the only futures not among the 
five most probable futures in the other two scenarios. The striking element in this future is the introduction of action from the Lebanese government as a result of Hezbollah's decision to attack Israel. This is the only of the five most probable alternate futures in any of the three scenarios that features Lebanese action beyond the scope of diplomacy.

In this future, Israel launches a full-scale invasion of Lebanon akin to alternate future \#9. The chief difference in this future is found in the actions of the Lebanese government, who would conduct a limited response of their own. In this future, the Lebanese government decides that Hezbollah's reckless "adventurism" against Israel represents a constant and existential threat to the national security and territorial integrity of Lebanon. While the government cannot engage in overt action for fear of Hezbollah reprisals, the government elects to provide Israel with logistical support. This action involves the government covertly passing information on Hezbollah's key military positions and known locations where Hezbollah's leadership may be hiding.

Whatever action the Lebanese government takes will be unilateral to the parties that execute the action. In other words, the government knows that any decision to engage Hezbollah will not enjoy broad support and will only use agents that can be completely trusted to conduct the operation with utmost secrecy. The overriding concern is that if the government is implicated in efforts to fight Hezbollah, particularly if aiding Israel, the country could slide into civil war. This concern is enhanced by American pressure on the Israelis to shorten the duration of the operation, enhancing the possibility that Hezbollah will emerge from the conflict largely capable of waging war with the government. Thus, the severe risk of this course of action is mitigated in the minds of the 
Lebanese government only by the concern that Hezbollah's continued provocations against Israel will lead to the ultimate demise of the Lebanese state.

The war will result in a diminished military capability for Hezbollah. However, the group will retain popularity among the Lebanese most affected by the Israeli operation, and more importantly, will bolster its case for retaining its arms. The war will increase Israel's deterrence posture against Hezbollah and likely quell Hezbollah's appetite to engage Israel so blatantly in the future.

Alternate Future \#18: Israel conducts a limited response to Hezbollah's direct military attack, while the United States and Lebanon choose to handle the situation through diplomatic channels.

This future received 24 votes, tying it with future \#8 as the second most likely future in this scenario. This future is included among the five most probable futures in each of the three scenarios. This represents the best-case scenario for peace in the Middle East, as Israel's response is limited in its scope.

In this future, Israel responds to Hezbollah's attack by launching a counterattack against the specific Hezbollah unit that is responsible for the attack. This will take the form of an IDF helicopter attack, coupled with a limited number of sorties over Lebanon, which target Hezbollah weapons depots and communication centers in the southern part of Lebanon. All Israeli action is limited to targets south of the Litani River. Israel follows these attacks with a warning to Hezbollah that if the group responds further, it could escalate the conflict and potentially trigger a full-scare war.

The United States will strongly condemn the Hezbollah provocation, while advocating the Israeli response on the pretense that Israel has a right to self-defense. The 
Obama administration will contact Netanyahu and Israeli Defense Minister Ehud Barak, expressing satisfaction with the Israeli response, which they will call "balanced" and "proportionate". The United States will publicly urge both sides to take steps to prevent further escalation in the conflict, while reminding Lebanon of its duty to disarm Hezbollah according to UN Resolution 1701.

The Lebanese government will publicly express disappointment with Hezbollah's attack on Israel, calling it a "reckless provocation". In private, the government will express the desire that Hezbollah refrain from such attacks in the future, and mention the potential for extensive damage to the Lebanese nation. The government will try to entreat Hezbollah to consider the welfare of the Lebanese public before undertaking such an action in the future. Lebanese comments on the Israeli counterstrikes will be limited to a desultory condemnation without further comment, in an effort to avoid fanning the flames of Israeli resentment over Hezbollah's actions.

Alternate Future \#6: Israel launches a full assault against Hezbollah in response to the group's direct military attack on Israel, while the United States pursues a limited response, and Lebanon pursues diplomatic channels to address the situation.

This future received 23 votes, making it the fourth most likely future in this scenario. This future is among the five most probable futures in each of the other three scenarios. This future is nearly identical to future \#9 except that the United States is taking a course of limited response.

In this future, Israel launches a full-scale invasion of Lebanon identical to that in future \#9. However, in this future, the United States takes part in the effort with a limited response. Due to Hezbollah's brazen attack against Israel, the United States will feel less 
reservation about providing logistical support to the Israelis. The logistical support takes the form of the sharing of intelligence on Hezbollah's movements and American support in crimping Hezbollah's supply line of weapons and resources from Iran. The United States Navy will be deployed to the eastern Mediterranean to assist in an Israeli blockade of Lebanon, under the pretense of cutting off a source of Hezbollah's weapons.

The United States will go to some length to ensure the Lebanese government that its actions are aimed only at confronting Hezbollah. To this end, the United States will take steps to discourage Israeli targeting of Lebanese civilian infrastructure and encourage an easing of the blockade to allow all vessels after a search to ensure that no weapons are aboard.

In this future, the Lebanese government issues a stronger condemnation of the attack, though still weak in comparison to condemnations from other nations. The Lebanese government will privately express extreme displeasure with Hezbollah for provoking not only a full Israeli assault, but also American assistance. Meanwhile, the government will publicly condemn the Israeli aggression and "disproportionate response", while calling on the United States to halt its assistance and complicity in the unwarranted aggression. The United States will counter that its only mission is to confront Hezbollah, and that it will strive to preserve Lebanese territorial integrity to the extent possible under the circumstances.

The war will result in a diminished military capability for Hezbollah. However, the group will retain popularity among the Lebanese most affected by the Israeli operation, and more importantly, will bolster its case for retaining its arms. The war will 
increase Israel's deterrence posture against Hezbollah and likely quell Hezbollah's appetite to engage Israel so blatantly in the future.

Hezbollah's reaction to this response would likely be to express regret that their attack could warrant such a response. This would no doubt be an attempt by Hezbollah to obtain sympathy and perhaps even establish a moral high ground by citing "disproportionate response" at the hands of two of the world's most powerful militaries. The United States will prove reliable in its material support for the Israeli invasion, and Hezbollah will surely look to frame the conflict as a clash of civilizations, evoking the imagery of the Crusades in an attempt to rally the Arab street to its banner. The diplomatic pressure created by such a strategy will certainly temper American support for the mission, and further destabilize the Middle East, while threatening remaining American troops in Iraq.

Alternate Future \#3: Israel and the United States launch a full-scale assault against Hezbollah in response to the group's attack on Israel, while Lebanon engages Hezbollah through diplomatic channels.

This future received 22 votes, making it the fifth most likely future in this scenario. This future and future \#8 are the only futures not among the five most probable futures in the other two scenarios. This is no doubt the result of this future being among the direst results of any Hezbollah action, as both Israel and the United States would bring the full brunt of their militaries down on Hezbollah.

In this future, Israel launches a full-scale invasion of Lebanon. Unlike the other futures, the United States joins Israel in this full-scale assault. The tactical ramifications become immediately apparent as the two nations struggle to decide which nation should 
take the lead in such matters as bombing sorties, troop deployment, and command of the combined force. The two nations agree to allow the IAF to conduct sorties over Lebanon, while IDF and American troops share the burden of conducting the ground operation under joint control of Israel and American generals. The United States Navy takes the lead in forming the blockade around Lebanon, while the United States Air Force takes the lead on patrolling the eastern border of Lebanon in an effort to halt the flow of weapons into Lebanon. The plan is made that after the offensive is completed, the American troops will withdraw and the IDF troops will remain to conduct cleanup operations within southern Lebanon. The United States will insist that the timetable for the operation is less than two weeks. Israel reluctantly agrees.

The operation proves successful at dislodging Hezbollah's main elements in southern Lebanon, but armed militias make life difficult on the IDF troops deployed there. Hezbollah's stronghold in the Bekaa Valley is devastated, and Hezbollah's offices in Beirut are destroyed. However, Hezbollah's leadership evades the bombs and raids of the IDF and American troops. The two-week deadline expires and the American troops begin their withdrawal as pressure mounts on the IDF to do the same. After a few days of lingering in Lebanon to find remaining elements of Hezbollah, the IDF withdraws under heavy international pressure and condemnation for the "disproportionate response" to Hezbollah's attack.

By virtue of the group's survival against the onslaught of the world's two most powerful militaries, Nasrallah will claim victory for Hezbollah. However, unlike 2006, the group sustains major damage and possesses only a fraction of its military power from before the war. The political cost of the operation is extremely high for Israel and the 
United States, who are both roundly condemned in the Middle East and by many other countries around the world. The United States loses its credibility as an arbitrator in the Middle East peace process, and Iran gains credibility across the Muslim world as only Islamic nation-state willing to confront American and Israeli "imperialism".

The Lebanese government condemns Hezbollah's attack on Israel as well as the Israeli and American response, calling it "exceedingly disproportionate". The government cuts off communications with Hezbollah for fear of being linked with the group during the intense onslaught. The economic effect of the war in Lebanon proves too much for the government, and the government is eventually ousted in the next general election, as Hezbollah and the March 8 Coalition are swept into power amid a tide of anti-Western sentiment in Lebanon.

In this scenario, among the five most probable futures, there is a 100-percent chance of an Israeli military response to the Hezbollah attack on Israel, with an 80percent chance that the response will involve a full-scale invasion of Lebanon. There is a 40-percent chance that the United States will respond with at least logistical support for an Israeli attack, and a 20-percent chance that the American response will be a full-scale assault in concert with Israel. There is a 20-percent chance that Lebanon might pursue a cautious limited response against Hezbollah if the group directly attacks Israel. According to the most probable futures in this scenario, a Hezbollah attack against Israel nearly assures that a full-scale war will erupt between the two actors.

\section{Scenario 3 - Hezbollah Provokes Israel to Attack}

In this scenario, Hezbollah attempts to actually provoke an Israeli attack. The reasons for Hezbollah to provoke an attack are varied and include a desire to reinforce 
their raison d'être by reminding the Lebanese of the threat that Israel poses, a desire to lure the IDF into well-laid traps in southern Lebanon, or at the insistence of Iran to deflect international attention from their nuclear program or other contentious issue. Hezbollah's provocation of Israel is made with the group holding three assumptions about a conflict with Israel:

1. The IDF cannot destroy Hezbollah.

2. The IDF cannot sustain an operation against Hezbollah without eventually running up an ever-increasing political cost.

3. The group's resistance against the IDF will endear it to a wider population within Lebanon and the Muslim world.

This understanding is necessary in order to consider the act of provocation to be one that is rational and entirely probable.

Hezbollah's options for provoking Israel to attack are multi-faceted. The group can provoke an Israeli attack through either provocative statements or provocative actions. Provocative statements would include threats to attack Israeli or Jewish targets abroad, threats to launch longer range missiles toward Tel Aviv, or loudly declaring the capability to launch rockets at Israel's primary population centers. More significant than statements, Hezbollah could elect to perform provocative actions such as approaching the border with heavily armed units, taking shots at IDF border patrols, or even launching a limited number of Katyusha rockets into Israel through a proxy group. While all of these examples are provocative, the provocative actions, more so than provocative statements, are much more likely to elicit a strong Israeli response that reaches beyond the scope of diplomacy.

This scenario is unique compared to the previous two scenarios. In the other two scenarios, one would be hard-pressed to make an argument against Hezbollah as the 
aggressor, despite the level of proportionate response offered by Israel. However, in this case, the international community will perceive any Israeli response beyond the realm of diplomacy as unwarranted Israeli aggression in the face of ostensibly harmless saber rattling from Hezbollah. This scenario's five most probable futures are all present in either one of the two other scenarios. However, the context of these responses is considerably different given the lack of substantial aggression from Hezbollah.

Alternate Future \#27: Israel, the United States, and Lebanon all pursue diplomatic options to respond to Hezbollah's provocations.

This future received 26 votes, making it the most likely future in this scenario. This future more or less represents the status quo as of July 2009, and the calmest state of relations between Israel and Hezbollah. Hezbollah frequently issues provocative statements, which are either ignored by Israel or responded to with provocative statements from Jerusalem. This future is also among the top five most probable futures in Scenario 1.

In this future, Israel chooses to give little heed to Hezbollah's provocations. The decision is a calculated one on the part of Israel, as an Israeli response would likely garner widespread condemnation from the international community. Instead of responding to Hezbollah threats, Israel chooses to issue threats of its own and wait for Hezbollah to provide a more substantive reason to pursue military action against the group.

The United States issues a statement calling on Israel to continue its display of restraint, while chiding Hezbollah for its provocations and accusing the group of being the primary catalyst for instability in the Middle East. Washington uses the opportunity 
to remind Beirut of the responsibility that it has to disarm Hezbollah under the provisions in UN Resolution 1701. The Lebanese government dismisses the American statement but otherwise remains publicly silent on the issue. However, the government expresses reservations to Hezbollah in private about the dangers of escalating the conflict.

While this future appears to avert war, the degree to which Hezbollah is willing to pursue a wider conflict with Israel will determine whether or not the group will continue to provoke Israel. In this future, Hezbollah continues to provoke Israel to attack using increasingly provocative methods, until Israel begins considering action beyond the scope of diplomacy to address the situation. This future represents the greatest potential of any future to be "transposed" into a scenario that represents an escalation of the conflict.

Alternative Future \#18: Israel conducts a limited response to provocations, while the United States and Lebanon choose to handle the situation through diplomatic channels.

This future received 25 votes, making it the second most likely future in this scenario. This scenario is among the top five futures in the other two scenarios. This future represents an escalation of the situation on the part of Israel, but only on a limited basis. The United States and Lebanon retain their distance from the conflict and attempt to address the issue through diplomatic channels only.

In this future, Israel issues a limited response in the form of an assassination attempt on a key Hezbollah military commander. The attempt is successful, and while Israel remains silent on its culpability, Hezbollah publicly blames Israel for the killing and vows revenge. Israel warns that any Hezbollah attack against Israel or Jewish targets abroad will draw a sharp Israeli response. The situation threatens to spiral out of control. 
The United States chides Hezbollah for its rhetoric and criticizes its role as a destabilizing element in the Middle East. After the assassination of the key Hezbollah commander, the United States remains silent on the issue, choosing to withhold judgment until the facts of the case come to light, but expresses disappointment that such an event will further destabilize the region. Washington warns both sides against escalating the conflict, and warns Lebanon and Hezbollah to abide by UN Resolution 1701.

The Lebanese government refuses to address Hezbollah's provocations publicly, but privately expresses reservations about Hezbollah's actions. The government joins in the condemnation of the assassination, but stops short of blaming Israel directly for the killing.

Alternate Future \#15: Israel and the United States pursue a limited response to the provocation, while Lebanon chooses to handle the situation through diplomatic channels.

This future received 24 votes, making it the third most likely future in this scenario. This future is among the five most probable futures in Scenario 1, and represents a deepening of the response to Hezbollah's provocations as the United States joins Israel in the limited response.

In this future, Israel elects to pursue a limited response nearly identical to that of future \#18 in this scenario. The chief difference in this scenario is that the United States also elects to pursue a limited response. The two nations work in concert to elicit the response. Because of the prohibition in American law against American intelligence agencies partaking in assassination attempts, the United States elects to provide Israel with intelligence on Hezbollah operatives in Europe. Israel proceeds to target a key 
member of Hezbollah's intelligence apparatus in Europe, successfully assassinating the operative.

Hezbollah issues a strong condemnation of the assassination and publicly accuses Israel of the killing, vowing revenge. However, the group is not aware of the connection that the United States has to the operation, and mentions the United States only as an enabler of Israeli "malfeasance". The Lebanese government remains silent on the issue publicly, only confronting Hezbollah in a private setting and expressing its reservation about the group's provocative actions.

Alternate Future \#9: Israel launches a full military assault against Hezbollah, while the United States and Lebanon choose to handle the situation through diplomatic channels.

This future received 23 votes, making it the fourth most likely future in this scenario. This future is present in the five most probable futures in each of the other two scenarios and represents a significant escalation of the conflict by Israel.

In this future, Israel launches a full-scale invasion of Lebanon, completely taking Hezbollah and the world by surprise. The surprise attack causes Hezbollah to be caught off-guard, having left key targets vulnerable to sorties by the IAF and the damage to Hezbollah's military capability is substantial during the first 48 hours of the conflict. The Israeli ground invasion begins within 72 hours of the first bombs falling on Lebanon, and the IDF is able to overwhelm and drive back the under-equipped Hezbollah forces in southern Lebanon, chasing elements of Hezbollah across the Litani River. Within the first five days of the conflict, the IDF has dealt a severe blow to Hezbollah's forces in southern Lebanon. However, Hezbollah uses the time it takes the IDF to advance in the south to firm its defenses in the Bekaa Valley and in positions north of the Litani River. 
The United States chides Hezbollah for its provocation, but urges Israel to show restraint. As the operation drags into its fifth day, the Obama administration expresses disappointment that Israel is responding "disproportionately" to the Hezbollah provocation and begins to exert significant pressure on Israel to withdraw its troops back across the border. Due to intense international and American pressure, the IDF withdraws from Lebanon seven days after the start of the conflict, never having capitalized on the initial momentum of the campaign.

The war proves unpopular in Israel and is seen as "adventurism" by a wide crosssection of Israeli society, which is embarrassed by the level of international condemnation for the Israeli invasion. Hezbollah and Iran strongly condemn Israeli "aggression" and express the need for Israel to be removed from the Middle East. Hezbollah pledges to redouble its efforts to recover from the onslaught and continue its fight against Israel. The Lebanese government condemns the Israeli invasion and files a complaint with the United Nations. Beirut threatens to deploy the Lebanese army on the border.

Alternate Future \#6: Israel launches a full assault against Hezbollah in response to the group's provocations, while the United States pursues a limited response, and Lebanon pursues diplomatic channels to address the situation.

This future received 20 votes, tying it with future \#17 for the fifth most likely future in this scenario. This analysis will only examine the effects of future \#6, rather than both futures. The reasons for this are two-fold. With only 20 votes, both futures are significantly less likely than the four more probable futures in this scenario, and an examination of two futures that are so much less likely is not likely to contribute to the 
analysis in a meaningful way. More importantly, when performing the pairwise comparison, future \#6 was chosen as more probable than future \#17.

In this future, Israel launches a surprise full-scale invasion of Lebanon in a manner identical to future \#9. The key difference in this future is that the United States is pursuing the course of limited response by providing Israel with covert logistical support. The United States provides Israel with its satellite imagery as well as SIGINT in an effort to bolster Israel's capability to conduct a quick and effective campaign against Hezbollah. The United States provides this assistance on the condition that the operation will last less than seven days, and Israel reluctantly agrees.

Publicly the United States urges both sides to show restraint and calls on Israel to limit its operation to Hezbollah targets. During the fifth day of fighting, the United States and Israel publicly declare that the Israeli operation will be over within 48 hours. Israel expresses a desire to have an additional 48 hours to conduct operations but is rebuffed by the United States.

Hezbollah suffers extensive damage to its military capability. The group publicly condemns the Israeli invasion with the strongest possible language. The group is unaware of the American involvement in the conflict but criticizes the United States for failing to reign in their ally sooner. Hezbollah pledges to redouble its efforts to rearm and further pledges to continue the fight against Israel. The Lebanese government condemns the Israeli invasion and files a complaint with the United Nations. Beirut threatens to deploy the Lebanese army on the border.

In this scenario, among the five most probable futures, there is an 80-percent chance that Hezbollah's provocations will elicit something stronger than diplomatic 
engagement from Israel. There is a 40-percent chance that Israel will launch a full-scale invasion of Lebanon, and a 40-percent chance that Israel will provide a limited response. The scope of the limited response will be covert and unlikely to result in an immediate escalation of the conflict. There is only a 40-percent chance that the United States will respond with something stronger than diplomatic engagement, and a 20-percent chance that the American response would be limited to covert logistical support, provided on condition of a quick Israeli withdrawal. Lebanon is 100-percent certain to keep its responses completely within the realm of diplomacy. While Hezbollah provocations represent a threat to Middle East stability, the threat is substantially smaller than in other scenarios, but could quickly escalate depending on the responses of the other actors. This scenario most closely resembles the current situation in the Middle East.

\section{Focal Events}

Focal events are occurrences that are significant enough to alter the relative probability of alternate futures (Lockwood 2008). Determining focal events is an important step in determining the probability of a possible future occurring. This step helps the analyst understand the present and the impact that future events will have on the responses of the affected actors. Generally, the alternate futures that differ the least from the status quo will require the fewest focal events to bring about the future (Lockwood 2008).

The future that most resembles the status quo is future \#6, in which Israel, the United States, and Lebanon all pursue diplomatic avenues to address the actions of Hezbollah. The scenario that most resembles the present is Scenario 3, where Hezbollah is issuing provocative statements and threats against Israel. In this case, the focal events 
will address the events that could change the probability of the alternate future for which the least resistance is needed to occur; in this case, alternate future \#6 in Scenario 3. Only one of these events may be necessary to change the probability of an alternate future, but more of these events may be required to occur before some of the less likely futures occur. The focal events are listed below and the indicators for these events are italicized and listed beneath each focal event.

$\underline{\text { Focal Events and Indicators }}$

- Hezbollah attacks Israeli or Jewish targets outside Israel.

- Hezbollah moves vital targets and personnel in Lebanon to safety in anticipation of Israeli response.

- Hezbollah issues a threat to attack Israeli or Jewish targets.

- Hezbollah operatives are spotted or arrested in a city with a large Jewish population.

○ Allusions to "coming victory" or "imminent good news" are present in Nasrallah's speeches.

- Nasrallah makes extensive mention of Imad Mugniyeh's assassination in his speeches.

- Hezbollah directly attacks Israel with premeditation and in force.

- There is increased Hezbollah reconnaissance activity near the Israel-Lebanon border.

- Hezbollah moves vital targets and personnel in Lebanon to safety in anticipation of Israeli response. 
- UNFIL personnel report increased Hezbollah activity in southern Lebanon.

- Iran is involved in domestic or international controversy.

- Hezbollah launches a small number of rockets into Israel through a proxy group.

- Hezbollah issues threats to Israel.

- Hezbollah moves vital targets and personnel in Lebanon to safety in anticipation of Israeli response.

- Hezbollah harasses IDF border patrols or kidnap IDF personnel.

- Increased Hezbollah reconnaissance activity near the IsraelLebanon border.

- Nasrallah makes extensive mention of the Shebaa Farms in his speeches.

- Nasrallah praises 2008 prisoner exchange or makes mention of Lebanese and Hezbollah prisoners being held in Israel.

- Hezbollah attacks Jewish targets in the United States, killing American Jews.

- Hezbollah moves vital targets and personnel in Lebanon to safety in anticipation of Israeli response.

- Hezbollah issues a threat to attack Israeli or Jewish targets.

- Hezbollah operatives are spotted or arrested in an American city with a large Jewish population.

- The United States Intelligence Community issues an alert that a terror attack is either imminent or of increased probability. 
○ Allusions to "coming victory" or "imminent good news" are present in Nasrallah's speeches.

- Nasrallah makes extensive mention of Imad Mugniyeh's assassination in his speeches.

- The United States completes withdrawal from Iraq.

- Troop deployments continue on schedule.

- The Iraqi security apparatus performs adequately.

- The United States successfully crushes rising Taliban threat in Afghanistan.

- Taliban forced to retreat from Pakistan.

- Obama makes less mention of the Taliban threat when discussing matters of national security.

- The Lebanese government adopts an assertive course of action against Hezbollah.

- The Lebanese government perceives an existential threat to Lebanon due to Hezbollah's actions and the threat of Israeli response.

- The Lebanese government becomes more outspoken in its criticism of Hezbollah.

- Hezbollah's actions draw strong indications of far-reaching Israeli response.

- Iran orders Hezbollah to provoke hostilities with Israel.

- Iran is involved in domestic or international controversy. 
- Ahmadinejad makes frequent reference to his skepticism over Holocaust and his desire to see Israel erased from the map.

- Iran is nearing completion of a crucial stage in its nuclear program.

- Iran achieves capability to build and deliver nuclear weapons as far as Israel.

- Hezbollah threatens American personnel in the Middle East.

- The United States becomes more outspoken in its criticism of Hezbollah.

- The United States is involved in a battle with Shia militants in Iraq.

- Security for American personnel remaining in Iraq is diminished due to troop withdrawal.

- Hezbollah kidnaps or kills American personnel.

- Hezbollah issues threat to American personnel.

- The United States becomes more outspoken in its criticism of Hezbollah.

- The United States is involved in a battle with Shia militants in Iraq.

- Security for American personnel remaining in Iraq is diminished due to troop withdrawal.

- Nasrallah makes extensive mention of American culpability with regard to Israeli actions.

- Hezbollah kills Lebanese politicians or members of the Lebanese armed forces. 
- The Lebanese government becomes more outspoken in its criticism of Hezbollah.

- Hezbollah and Lebanese armed forces clash.

- Members of the Lebanese government become outspoken critics of Syria or Iran.

- The Lebanese government attempts to stifle Hezbollah attempts to organize protests.

- Israel launches full-scale assault on Hezbollah.

- The IDF is placed on high alert.

- Heavy IDF mobilization begins in northern Israel.

- IDF patrols on the Lebanese border cease.

- Weapons, food, and medical supplies are moved toward the Lebanese border.

- IDF units in training are recalled from exercises.

- The IDF calls up reserve units.

- IAF pilots' leave is cancelled.

- Preparations for Jewish Shabbat or other High Holiday are eschewed (if applicable).

- The IAF increases the number of reconnaissance missions over Lebanon.

- The Israeli Navy moves toward Lebanese waters.

- Israeli residents in the north are advised to remain near protective bunkers. 
- The United States upholds Israeli right to self-defense.

- Israel carries out limited military strikes.

- The IAF increases the number of reconnaissance missions over Lebanon.

- Moderate IDF mobilization begins in northern Israel.

- IDF patrols on the Lebanese border decrease.

- The IDF is placed on high alert.

- The United States upholds Israeli right to self-defense.

- Israel carries out targeted killing operations.

- Israel issues threats and warnings to Hezbollah leadership.

- The IAF begins reconnaissance flights over the homes and known hideouts of Hezbollah leaders.

- Hezbollah leaders are killed under suspicious or violent circumstances.

- Israel limits its response or withholds from attacking Hezbollah at all.

- Israel declares a willingness to work as equal partners with the United States toward a general settlement with the Arab world.

- The United States indicates a willingness to reduce the level of economic aid going to Israel.

- The United States agrees to fund the building of more desalination plants in Israel.

- The United States supports Israel's claim on the Golan Heights. 
- The United States agrees to deemphasize opposition to Israel's program of building settlements in the West Bank.

- Israeli public opinion is strongly against another war.

- The IDF does not mobilize its troops.

- The IDF is engaged in another war.

- The ruling Center-Right coalition falls apart and Netanyahu government fails to secure support in the Knesset for major policy decisions.

- The United States pursues a military option against Hezbollah.

- Hezbollah attacks Jewish targets in the United States, killing American citizens.

- The Obama administration gains Congressional support for action against Hezbollah.

- The United States Navy deploys in the eastern Mediterranean.

- The United States has completed the withdrawal from Iraq.

- The United States successfully crushes rising Taliban threat, freeing resources for use against Hezbollah.

- The United States pledges to support the integrity of Israeli security.

- Obama makes reference to Hezbollah as a catalyst for instability in the Middle East.

- The United States tones down its response. 
- The Obama administration fails to gain Congressional support for action against Hezbollah.

- The timetable for the Iraq withdrawal is extended.

- The war in Afghanistan takes a turn for the worse, occupying more resources.

- The Obama administration and Democratic Congress suffer from low approval ratings during either the 2010 mid-term or 2012 Presidential election year.

- Oil prices begin to spike as a result of the increasingly volatile situation.

The number of focal events and indicators associated with this situation are vast and potentially infinite. Only the most probable focal events and indicators have been included here in an effort to make this analysis more concise, palatable, and relevant. However, as events continue to unfold in the future, this list of focal events and indicators will undoubtedly need to be updated, and so this list should be considered as nothing more than a snapshot of the situation in late-July 2009.

\section{Transposition of Alternate Futures}

The final step of the LAMP method involves analyzing the possibility of the transposition of one alternate future into another alternate future. Transposition occurs when the events of one future change the perceptions and courses of action for the actors, transposing the original alternate future into another alternate future. After a possible future has transposed into another, the probabilities for each possible future change. The opportunities for transposition between any two alternate futures may not necessarily be 
as abundant as the opportunities for transposition among a separate pair of futures. The opportunities for transposition among the five most probable futures in each scenario will be analyzed.

\section{Scenario 1 - Hezbollah Terror Attack Against Israeli or Jewish Target Abroad}

Alternate Future \#18: Israel conducts a limited response to the terror attack, while the United States and Lebanon choose to handle the situation through diplomatic channels.

This future is the most likely future in this scenario. This future provides ample opportunity to transpose into future \#9 if Hezbollah chooses to escalate the conflict by retaliating against Israel's limited response by either launching a military attack or conducting another terror attack against an Israeli or Jewish target abroad. Israel chooses in this future to escalate the level of its response accordingly and launch a full-scale invasion of Lebanon. Meanwhile, the United States condemns the escalation by Hezbollah, while urging restraint and a speedy operation by Israel. The Lebanese government will publicly chastise Hezbollah for its "reckless adventurism", and will condemn the Israeli response as "disproportionate".

Conversely, this future could transpose into future \#27 if Hezbollah were to refrain from retaliating for the limited Israeli response. In this future, Hezbollah publicly condemns the Israeli action and threatens revenge. Israel responds by warning Hezbollah that further provocations will draw another Israeli response, the degree of which will be determined later. The United States will urge both sides to exercise restraint, and the Lebanese government will remain silent publicly, while privately expressing reservations to Hezbollah about the group's provocative behavior. 
Alternate Future \#9: Israel launches a full military assault against Hezbollah, while the United States and Lebanon choose to handle the situation through diplomatic channels.

The second most likely future in this scenario does not have as much potential to transpose into another future. This is due in large part to the nature of Israel's response, which represents the highest level of escalation in the conflict. Therefore the only possibility in this conflict is for both sides to tone down the level of aggression, transposing into future \#27.

In this future, Israel faces immense pressure from the international community to put an end to the operation. Eventually, the Obama administration will feel intense pressure to urge Israel to withdraw its forces from Lebanon. Israel reluctantly agrees, phasing the withdrawal out over a 72-hour period. Hezbollah, trying to recover from the onslaught, makes no effort to engage or provoke the IDF further. Once the IDF has returned to Israel, Hezbollah and the Israeli government will exchange warnings and threats, as both sides seek to frame the conflict in a manner that portrays their side in a better light to the international community.

Alternate Future \#15: Israel and the United States pursue a limited response to the terror attack, while Lebanon chooses to handle the situation through diplomatic channels.

This future provides some opportunity to transpose into either future \#9 or future \#27. The potential for transposition stems from the response that Hezbollah provides to the limited response of Israel and the United States. Due to the covert nature of American participation, Hezbollah will not be aware of the role that the United States played in the assassination of one of its operatives. 
Hezbollah can elect to respond with another terror attack abroad or with a direct military attack on Israel. In this future, Israel responds to the escalation with a full-scale assault on Hezbollah, transposing this future into future \#9. If Hezbollah chooses not to retaliate for the limited response, this future will transpose into future \#27, as Hezbollah will issue a condemnation and threaten revenge. Israel will respond with threats and warnings of its own.

Alternate Future \#27: Israel, the United States, and Lebanon all pursue diplomatic options to respond to Hezbollah's terror attack.

This future, due to its low level of escalation, provides ample opportunity to transposition. If Hezbollah wishes to provoke Israel to attack, the group can escalate the conflict by either take more provocative courses of action, conducting a terror attack abroad, or directly attacking Israel. Israel's responses to these actions will determine the degree of transposition.

If Israel elects to provide a limited response, the future will transpose to future $\# 18$.

If Israel decides to launch a full-scale invasion of Lebanon, this future will transpose to future \#9.

Alternate Future \#6: Israel launches a full assault against Hezbollah in response to the terror attack, while the United States pursues a limited response, and Lebanon pursues diplomatic channels to address the situation.

This future provides ample opportunity for transposition despite the high state of escalation that this future represents. The United States can either further its involvement 
in the conflict, transposing this future into future \#3, or withdraw from the conflict, transposing this future into future \#9.

In future \#3, Hezbollah will decide to engage American forces in Iraq, killing several in ambushes. The United States responds by escalating its involvement in the Lebanese conflict, in essence declaring all-out war against Hezbollah. The United States decides to coordinate the invasion with Israel, providing Naval security and aerial monitoring of eastern Lebanon in an effort to stem the flow of weapons from Syria and Iran. After enduring significant international pressure to halt the operation, the United States and Israel withdraw. Hezbollah's leadership survives the war, but the group sustains a severe blow to its military capacity. However, the United States and Israel pay a significant political cost to achieve this objective.

In future \#9, the United States begins to suffer higher-than-expected casualties in Lebanon. This development sours the American public and government on the merits of continued American involvement in Lebanon, and the United States withdraws from the country. The IDF continues the fight, but the confusion caused by the sudden American withdrawal stalls the IDF operation, and Israel withdraws its military from Lebanon. Hezbollah suffers damage to its military capabilities, but is able to claim a victory, pointing the haphazard nature of the American and Israeli withdrawals.

The last opportunity for transposition stems from an Israeli decision to halt its operation in Lebanon, transforming this future into future \#27. In this future, Israel begins to suffer higher-than-expected casualties and pressure mounts among the Israeli public to end the war. The government, afraid of its tenuous hold to power, acquiesces to the public demand and withdraws from the country. The United States, which limited its 
response to logistical support, no longer has a mission in Lebanon and leaves the region. Hezbollah claims a victory despite the extensive damage done to Lebanon, while Israel begins the process of examining its shortcomings in yet another flawed invasion of Lebanon.

In addition to the analysis of each of the top five most likely futures in this scenario, there is a special consideration for transposition. If Hezbollah attacks an Israeli or Jewish target within the United States, and American citizens are killed, any of the given alternate futures could transpose into future \#3, which is a joint full-scale invasion of Lebanon by the United States and Israel, or future \#6, in which the United States provides a limited response in the form of support for an Israeli invasion. Future \#15, a joint limited response by the United States and Israel is possible, but it is likely that if given the free reign and overt moral support by the United States to pursue a full-scale invasion of Lebanon, that Israel will adopt this course of action. The same opportunities for transposition exist in the event that Hezbollah kidnaps, kills, or otherwise overtly engages American forces or personnel in the Middle East.

\section{Scenario 2 - Hezbollah Conducts Direct Military Attack Against Israel}

Alternate Future \#9: Israel launches a full military assault against Hezbollah, while the United States and Lebanon choose to handle the situation through diplomatic channels.

The most likely future in this scenario does not have as much potential to transpose into another future. This is due in large part to the nature of Israel's response, which represents the highest level of escalation in the conflict. Therefore the only possibility in this conflict is for both sides to tone down the level of aggression, 
transposing into future \#27. This possibility exists primarily because a state of war between Israel and Hezbollah is unsustainable for either side and cannot last indefinitely.

In this future, Israel faces limited but increasing pressure from the international community to put an end to the operation as it begins to drag out into its fourth week. Despite supporting Israel's right to self-defense, the Obama administration will eventually feel intense pressure to urge Israel to withdraw its forces from Lebanon. Israel reluctantly agrees, phasing the withdrawal out over a 72-hour period. Hezbollah, trying to recover from the onslaught, makes no effort to engage or provoke the IDF further. Once the IDF has returned to Israel, Hezbollah and the Israeli government will exchange warnings and threats, as both sides seek to frame the conflict in a manner that portrays their side in a better light to the international community.

Alternative Future \#8: Israel launches a full-scale invasion of Lebanon, the United States pursues a diplomatic option, and Lebanon pursues a limited response to Hezbollah's attack on Israel.

This future presents limited opportunity for transposition. Like future \#9 above, this future has the potential to transpose to future \#27. The unique case of transposition for this future will emerge out of Lebanon's hesitancy to involve itself in a struggle against Hezbollah.

In this future, Lebanon regrets its decision to take the course of limited response by cooperating with Israel. Spurred on by regret and fear of reprisal by Hezbollah, the Lebanese government cuts off communication with the IDF, and instead encourages Hezbollah to take steps to end the war with Israel. The IDF does not suffer as a result of 
Lebanon's decision and continues with the operation until it is pressured by the United States to withdraw its forces from Lebanon.

Hezbollah's military capability will be diminished, but the group will retain the popularity it has achieved in Lebanon. Israel, having evidence of Lebanon's cooperation with the IDF, explores options to blackmail the Lebanese government by threatening to release the evidence of its collusion with Israel during the invasion.

Alternate Future \#18: Israel conducts a limited response to Hezbollah's direct military attack, while the United States and Lebanon choose to handle the situation through diplomatic channels.

This future provides ample opportunity to transpose into future \#9 if Hezbollah chooses to escalate the conflict by retaliating against Israel's limited response. Because Israel will perceive its initial response as one defined by its restraint, retaliation by Hezbollah will decrease Israeli inhibitions about expanding its response. Israel chooses in this future to escalate the level of its response accordingly and launch a full-scale invasion of Lebanon. Meanwhile, the United States condemns the escalation by Hezbollah, while urging restraint and a speedy operation by Israel. The Lebanese government will publicly chastise Hezbollah for its "reckless adventurism", and will condemn the Israeli response as "disproportionate".

Conversely, this future could transpose into future \#27 if Hezbollah were to refrain from retaliating for the limited Israeli response. In this future, Hezbollah threatens revenge but also claims that Israel's limited response was proof of the nation's "lack of resolve". Israel responds by warning Hezbollah that further provocations will draw another stronger Israeli response, the degree of which will be determined later. The 
United States will urge both sides to exercise restraint, and the Lebanese government will remain silent publicly, while privately expressing reservations to Hezbollah about the group's provocative behavior.

Alternate Future \#6: Israel launches a full assault against Hezbollah in response to the group's direct military attack on Israel, while the United States pursues a limited response, and Lebanon pursues diplomatic channels to address the situation.

This future provides ample opportunity for transposition despite the high state of escalation that this future represents. The United States can either further its involvement in the conflict, transposing this future into future \#3, or withdraw from the conflict, transposing this future into future \#9.

In future \#3, Hezbollah will decide to engage American forces in Iraq, killing several in ambushes. The United States responds by escalating its involvement in the Lebanese conflict, in essence declaring all-out war against Hezbollah. The United States decides to coordinate the invasion with Israel, providing Naval security and aerial monitoring of eastern Lebanon in an effort to stem the flow of weapons from Syria and Iran. Despite a strong casus belli for both Israel and the United States, significant international pressure builds to halt the operation as it enters its third week. After brief negotiations between the United States, Israel, Lebanon, Hezbollah, and the United Nations, the United States and Israel withdraw. Hezbollah's leadership survives the war, but the group sustains a debilitating blow to its military capacity. The United States and Israel pay a significant political cost for the operation, but enjoy a modicum of private support from world leaders who perceive that both nations had reasonable cause to invade Lebanon. 
In future \#9, the United States begins to suffer higher-than-expected casualties in Lebanon. This development sours the American public and government on the merits of continued American involvement in Lebanon, and the United States withdraws from the country. The IDF continues the fight without American assistance, but international pressure builds more quickly as a result of the American pullout. The IDF halts the advance on its ground invasion and focuses on destroying Hezbollah's military infrastructure in southern Lebanon. After the conflict enters its fourth week, the United States begins to join the chorus of nations that are urging Israel to wrap up its operation. Israel unilaterally withdraws from Lebanon less than five weeks after the start of hostilities.

The last opportunity for transposition stems from an Israeli decision to halt its operation in Lebanon, transforming this future into future \#27. In this future, Israel begins to suffer higher-than-expected casualties and pressure mounts among the Israeli public to end the war. The government, afraid of its tenuous hold to power, acquiesces to the public demand and withdraws from the country. The United States, which limited its response to logistical support, no longer has a mission in Lebanon and leaves the region. Hezbollah claims a victory despite the extensive damage done to Lebanon, while Israel begins the process of examining its shortcomings in yet another flawed invasion of Lebanon.

Alternate Future \#3: Israel and the United States launch a full-scale assault against Hezbollah in response to the group's attack on Israel, while Lebanon engages Hezbollah through diplomatic channels. 
This future provides little room for transposition into another probable future. The only reasonable transposition is into future \#27. This possibility exists primarily because a state of war between Israel and Hezbollah is unsustainable for either side and cannot last indefinitely. However, there are opportunities for a premature end to the hostilities that results in future \#27.

In this future, the United States and Israel launch a devastating invasion of Lebanon. The combined forces of the United States and Israel quickly overwhelm Hezbollah forces in the south, and the operation begins to spread toward the Bekaa Valley and the southern outskirts of Beirut. The alarming rate of the advance stuns the Lebanese government. The government condemns the invasion, calling it "exceedingly disproportionate", and threatens to put the Lebanese army between the combined American-Israeli force and further advancement into Lebanon. The United States and Israel halt their advance, unwilling to directly challenge Lebanese sovereignty and trigger a regional war by engaging the national army.

With little recourse to expand the operation, the United States and Israel begin preparations to wrap up the operation amid growing international pressure on the two nations to quit Lebanon. Within three weeks of invading Lebanon, the United States and Israel withdraw their forces, leaving a battered country. Hezbollah sustains considerable damage to its military apparatus, and pledges to redouble its efforts at rearmament and pledges to continue its struggle against Israel.

As with Scenario 1, any Hezbollah attack that directly affects American citizens or personnel is likely to steel the American resolve to confront Hezbollah. However, because a Hezbollah terror attack is off the table in this scenario, the strong sentiment and 
conviction that such an event would stir among the American public and government is absent.

\section{Scenario 3 - Hezbollah Provokes Israel to Attack}

Alternate Future \#27: Israel, the United States, and Lebanon all pursue diplomatic options to respond to Hezbollah's provocations.

This future, due to its low level of escalation, ostensibly provides ample opportunity to transposition. However, upon closer inspection, this scenario constricts Hezbollah inciting course of action to mere provocation. If Hezbollah wishes to provoke Israel to attack, the group can escalate the conflict only by taking more provocative courses of action until Israel finally responds with force, transposing this future into future \#18.

In this future, Hezbollah's provocations continue until the group finally launches a small number of Katyushas that fall near the northern Israeli town of Nahariya. Israel responds with a short series of bombing sorties, targeting Hezbollah communications and command centers in southern Lebanon.

Future \#27 can transpose into future \#9, but only incrementally, through a series of escalations during which the future is first transposed into future \#18, as demonstrated in the previous paragraph. Hezbollah's reaction to this response escalates the conflict. A group of Hezbollah members crosses the border into Israel and ambushes an IDF patrol, killing several IDF personnel. Israel decides to pursue a more expansive response and launches a full-scale assault on Hezbollah, transposing this future in future \#9.

Alternative Future \#18: Israel conducts a limited response to provocations, while the United States and Lebanon choose to handle the situation through diplomatic channels. 
This future provides ample opportunity to transpose into future \#9 if Hezbollah chooses to escalate the conflict by retaliating against Israel's limited response. Israel chooses in this future to escalate the level of its response and launches a full-scale invasion of Lebanon. Meanwhile, the United States condemns the escalation by Hezbollah, while expressing disappointment with the operation by Israel. The Lebanese government will publicly chide Hezbollah for its provocations, and will condemn the Israeli response as "disproportionate".

Conversely, this future could transpose into future \#27 if Hezbollah were to refrain from retaliating for the limited Israeli response. In this future, Hezbollah threatens revenge but also claims that Israel's limited response was proof of the nation's "lack of resolve". Israel responds by warning Hezbollah that further provocations will draw another stronger Israeli response, the degree of which will be determined later. The United States will urge both sides to exercise restraint, and the Lebanese government will remain silent publicly, while privately expressing reservations to Hezbollah about the group's provocative behavior.

Alternate Future \#15: Israel and the United States pursue a limited response to the provocation, while Lebanon chooses to handle the situation through diplomatic channels.

This future provides some opportunity to transpose into either future \#9 or future \#27. The potential for transposition stems from the response that Hezbollah provides to the limited response of Israel and the United States. Due to the covert nature of American participation, Hezbollah will not be aware of the role that the United States played in the assassination of one of operatives. 
Hezbollah can elect to respond with a terror attack abroad or with a direct military attack on Israel. In this future, Israel responds to the escalation with a full-scale assault on Hezbollah, transposing this future into future \#9. If Hezbollah chooses not to retaliate for the limited response, this future will transpose into future \#27, as Hezbollah will issue a condemnation and threaten revenge. Israel will respond with threats and warnings of its own.

Alternate Future \#9: Israel launches a full military assault against Hezbollah, while the United States and Lebanon choose to handle the situation through diplomatic channels.

This future does not have as much potential to transpose into another future in this scenario. This is due in large part to the nature of Israel's response, which represents the highest level of escalation in the conflict. Therefore the only possibility in this conflict is for both sides to tone down the level of aggression, transposing into future \#27.

In this future, Israel faces immense pressure from the international community to put an end to the operation, and is widely condemned for "disproportionate response" to Hezbollah saber rattling. Eventually, the Obama administration will feel intense pressure to urge Israel to withdraw its forces from Lebanon. Israel reluctantly agrees, phasing the withdrawal out over a 72-hour period. Hezbollah, trying to recover from the onslaught, makes no effort to engage or provoke the IDF further. Once the IDF has returned to Israel, Hezbollah and the Israeli government will exchange warnings and threats, as both sides seek to frame the conflict in a manner that portrays their side in a better light to the international community. However, Israel will suffer a significant political cost for carrying out the operation, because of global perceptions that Israel "overreacted" to the threat posed by Hezbollah. 
Alternate Future \#6: Israel launches a full assault against Hezbollah in response to the group's provocations, while the United States pursues a limited response, and Lebanon pursues diplomatic channels to address the situation.

This future provides ample opportunity for transposition despite the high state of escalation that this future represents. The United States can either further its involvement in the conflict, transposing this future into future \#3, or withdraw from the conflict, transposing this future into future \#9.

In future \#3, Hezbollah will decide to engage American forces in Iraq, killing several in ambushes. The United States responds by escalating its involvement in the Lebanese conflict, in essence declaring all-out war against Hezbollah. The United States decides to coordinate the invasion with Israel, providing Naval security and aerial monitoring of eastern Lebanon in an effort to stem the flow of weapons from Syria and Iran. After enduring international condemnation for the "irresponsible escalation" of the conflict and facing significant pressure to halt the operation, the United States and Israel withdraw. Hezbollah's leadership survives the war, but the group sustains a severe blow to its military capacity. However, the United States and Israel pay a significant political cost to achieve this objective.

In future \#9, the United States begins to suffer higher-than-expected casualties in Lebanon. This development sours the American public and government on the merits of continued American involvement in Lebanon given the weak casus belli, and the United States withdraws from the country. The IDF continues the fight, but the confusion caused by the sudden American withdrawal stalls the IDF operation, and Israel withdraws its military from Lebanon. Hezbollah suffers damage to its military capabilities, but is 
able to claim a victory, pointing the haphazard nature of the American and Israeli withdrawals.

The last opportunity for transposition stems from an Israeli decision to halt its operation in Lebanon, transforming this future into future \#27. In this future, Israel begins to suffer higher-than-expected casualties and pressure mounts among the Israeli public to end the war especially in light of the weak casus belli. The government, afraid of its tenuous hold to power, acquiesces to the public demand and withdraws from the country. The United States, which limited its response to logistical support, no longer has a mission in Lebanon and leaves the region. Hezbollah claims a victory despite the extensive damage done to Lebanon, while Israel begins the process of examining its shortcomings in yet another flawed invasion of Lebanon. Unlike in the aftermath of the 2006 war, Israel will determine that there was not sufficient reason to initiate such an illfated operation, and the Likud party will suffer significantly during the next general election.

\section{Conclusion}

It is extremely unlikely that Hezbollah will abandon its mission to struggle against Israel. The struggle against Israel was a fundamental element behind the group's formation and has come to define the group's role within Lebanon and, increasingly, within the Muslim world as a whole. Unlike the nation-state militaries that marched on Israel under the banner of Pan-Arabism during the 1960s and 1970s, Hezbollah has enjoyed a reasonable level of success against the IDF.

Hezbollah's provocations are likely to draw an Israeli response of some kind in the future. In 2006, Hezbollah failed to recognize the proverbial "line in the sand" that 
Israel had drawn, and the group's seemingly innocuous provocation prompted a staggering Israeli response. There is potential that the group could cross this line again by attacking an Israeli or Jewish target, particularly if the attack results in a high casualty count. Hezbollah has issued threats that it would conduct such an attack, and a thwarted attack in Baku earlier in 2009 is an ominous indicator that the group is pursuing a line of engagement that could push it and Israel to the brink of war.

Israel's utter unwillingness to define what action would warrant a limited response or a full-scale assault is a principled decision that is made in an effort to enhance strategic deterrence. Hezbollah, by virtue of its mission to confront Israel, is likely to try and strike a balance between a level of provocation that weakens Israeli resolve to resist concessions in the peace process without provoking Israel to a full-scale assault. The chances that Hezbollah will succeed in this effort in the long term are almost non-existent. The analysis of alternate futures and the potential for transposition eventually point to a full-scale Israeli operation against Hezbollah at some point in the future.

The United States is likely to exercise a degree of patience when confronting the prospects for war between Israel and Hezbollah. The potential for war in the Middle East is a concern for the United States as it begins a phased withdrawal from Iraq, and attempts to regain legitimacy as an arbitrator in the peace process between Israel and the Palestinians. A spike in oil prices that would accompany renewed hostilities between Israel and Hezbollah would adversely affect the deep recession that the United States is facing. In the event of a strong Hezbollah provocation, the Obama administration will find itself in the unenviable position of trying to coerce an increasingly suspicious and 
cynical ally to show restraint. If Israel launches a full-scale invasion, the United States would find itself in the position of trying to balance its promises to respect Israel's right to self-defense with its efforts to regain the goodwill of the Muslim world and the European Union, who would surely condemn any far-reaching Israeli response.

The Lebanese government is not enamored of Hezbollah's attempts to confront Israel, but is essentially powerless to confront the group in any meaningful way. The Lebanese government is likely to be spurred to action only if it senses an existential threat to its existence or if it enjoys the full support of the United States. The latter is extremely unlikely, and Hezbollah will take steps to ensure that the government does not perceive the former to be the case. The greatest asset of the Lebanese government is its ability to put its army between an invading force and Hezbollah positions. Such a move is extremely risky, but likely to impair efforts to further engage Hezbollah, as an attack against the Lebanese army would draw round condemnation from across the world.

Because of the prospect for American retaliation in concert with Israel, Hezbollah is extremely unlikely to conduct a terror attack against a Jewish target in the United States, or attack American interests overseas. The group apparently recognizes this truism and has attempted attacks in cities of countries such as Argentina and Azerbaijan, which lack the willingness or capacity to retaliate for such attacks. Due to the international distribution of the Jewish population, Hezbollah's potential list of targets is long, and while the Baku attack was thwarted, a determined campaign to conduct such an attack is likely to achieve success eventually. Such an attack is likely Hezbollah's best chance to inflict a significant wound on Israel while avoiding a significant Israeli response. 
Whether Hezbollah intends to simply maintain its current level of rhetoric and provocation, or whether the group decides to take more aggressive actions, such as conducting a terror attack or launching a military attack of some kind against Israel, the group will continue to hold the world's interest. In particular, Israel, the United States, and Lebanon will be significantly affected, and the courses of action of each actor will have a direct effect on Hezbollah. The conflict between Israel and Hezbollah is of vital strategic interest to all four actors, and represents the most significant threat to stability in the Middle East.

Instability in the Middle East has global repercussions. The sharp divide in world opinion notwithstanding, conflicts in the Middle East put significant upward pressure on crude oil prices. This makes the promotion of peace a high priority among the world's leading consumers of oil, especially for the United States, who remains the world's leading oil consumer. As long as Hezbollah retains its core mission of struggle against Israel, that peace is likely to remain elusive. 


\section{References}

Al-Jazeera. "Iran recount gives Ahmadinejad win.” AlJazeera.net. June 29, 2009. http://english.aljazeera.net/news/middleeast/2009/06/2009629151258105455.html (accessed June 29, 2009).

Amal Movement. Amal-Movement.com. http://www.amal-movement.com/indexa1.htm (accessed May 16, 2009).

Amnesty International. Amnesty International Report on Lebanon 2006. London: Amnesty International, 2006.

An-Nahar (reported on Now Lebanon). "Lebanese press round-up: December 17, 2008." AnNahar. December 17, 2008. http://nowlebanon.com/NewsArticleDetails.aspx?ID=71161\&MID=101\&PID=2 (accessed June 10, 2009).

Aronson, Shlomo. 2009. Israel's Security and the Holocaust: Lessons Learned, but Existential Fears Continue. Israel Studies 14, no. 1: 65-93.

Asharq Alawsat. "Reaction to Obama's Speech to the Muslim World." Asharq Alawsat. http://www.aawsat.com/english/news.asp?section=1\&id=16967 (accessed June 5, 2009).

Bar, Shmuel. 2007. Deterring Nonstate Terrorist Groups: The Case of Hizballah. Comparative Strategy 26, no. 5: 469-493.

Benhorin, Yitzhak. "Biden: Israel has 'sovereign right' to attack Iran.” YNet News. July 6, 2009. http://www.ynetnews.com/articles/0,7340,L-3741697,00.html (accessed July 6, 2009).

BBC News A. "Hezbollah warns Israel over raids." BBC News. July 12, 2006.

http://news.bbc.co.uk/2/hi/middle_east/5173078.stm (accessed June 4, 2009).

— B. "Iran Charged over Argentina Bomb." BBC News. October 25, 2006. http://news.bbc.co.uk/2/hi/americas/6085768.stm (accessed June 13, 2009).

_ C. "India Launches Israeli Satellite." BBC News. January 21, 2008. http://news.bbc.co.uk/2/hi/south_asia/7199736.stm (accessed June 3, 2009).

Brilliant, Joshua. 2006. "Analysis: Hezbollah's recovery timetable." UPI International Intelligence International Security \& Counter Terrorism Reference Center, EBSCOhost (accessed June 12, 2009).

Central Intelligence Agency. Lebanon. CIA World Factbook. https://www.cia.gov/library/publications/the-world-factbook/geos/le.html (accessed May $15,2009)$. 
Cooper, Helene and Eric Schmitt. White House Debate Led to Plan to Widen Afghan Effort. NYTimes.com. March 27, 2009. http://www.nytimes.com/2009/03/28/us/politics/28prexy.html (accessed May 6, 2009).

Defense News. "U.S. to Supply Tanks to Lebanon in Spring 2009." Agence France Presse. December 12, 2008. http://www.defensenews.com/story.php?i=3871558 (accessed June 10, 2009).

Dickey, Christopher. 2009. A Measured Victory in Lebanon. Newsweek. http://www.newsweek.com/id/201165 (accessed June 9, 2009).

Erlanger, Steven. 2006. As Israel Begins to Pull Troops Out, Lebanon and the U.N. Prepare to Replace Them. The New York Times. August 16. http://www.nytimes.com/2006/08/16/world/middleeast/16mideast.html (accessed May 22, 2009).

Eshel, David. 2008. The Golan Heights Will Remain Israel's Strategic Bulwark. Defense Update. http://defense-update.com/analysis/analysis_040508_golan.htm (accessed June 17, 2009).

[Fadlallah, Sheikh Muhammad Hussein?]. 1988. An Open Letter: The Hizballah Program. Trans. Jerusalem Quarterly. Jerusalem Quarterly, no. 48 (Fall). http://www.ict.org.il/Articles/tabid/66/Articlsid/4/currentpage/1/Default.aspx (accessed June 20, 2009).

Federal Bureau of Investigation. Terrorism 2002-2005. Terrorism in the United States. 2005. http://www.fbi.gov/publications/terror/terrorism2002_2005.htm (accessed June 17, 2009).

Feith, Daniel. 2003. The Costs of U.S. Aid to Israel. Harvard Israel Review. http://www.hcs.harvard.edu/ hireview/content.php?type=article\&issue=spring04/\&name $=$ feith $($ accessed June 24, 2009).

France 24. "Beirut street clashes turn deadly." France 24. May 9, 2008. http://www.france24.com/en/20080509-gunmen-force-shutdown-pro-government-tvlebanon-unrest\&navi=MONDE?q=node/1671710 (accessed June 10, 2009).

Gallup. "Obama Praised for Effort, Knocked for Spending." Gallup.com. July 15, 2009. http://www.gallup.com/poll/121685/Obama-Praised-Effort-Knocked-Spending.aspx (accessed July 16, 2009).

Geo-Strategy Direct. "Hizbullah quietly rearms in Lebanon, storing thousands of rockets in private buildings." International Security \& Counter Terrorism Reference Center, EBSCOhost (accessed June 14, 2009). 
Global Security A. Hizballah (Party of God). GlobalSecurity.org. http://www.globalsecurity.org/military/world/para/hizballah.htm (accessed May 16, 2009).

— B. Israel - IAF Equipment. GlobalSecurity.org. http://www.globalsecurity.org/military/world/israel/iaf-equipment.htm (accessed June 1, 2009).

Haaretz Staff. "The main findings of the Winograd partial report on the Second Lebanon War." Haaretz.com.

http://www.haaretz.com/hasen/objects/pages/PrintArticleEn.jhtml?itemNo=854051 (accessed June 14, 2009).

Hamzeh, A. Nizar. Lebanon's Hizbullah: from Islamic revolution to parliamentary accommodation. Third World Quarterly 14, no. 2.

Hazo, Robert G. The Vanished Imam: Musa al Sadr and the Shia of Lebanon. The Washington Report on Middle East Affairs 5, no. 5: 12.

Honig, Or. 2007. The End of Israeli Military Restraint. Middle East Quarterly 14, no. 1 (Winter): 63-74.

India Defence Staff. 2008. Israel Likely to Train Indian Counter Terror Special Forces. India Defence. http://www.india-defence.com/reports-4016 (accessed July 10, 2009).

Israel Ministry of Foreign Affairs. Elections in Israel - February 2009. Israel Ministry of Foreign Affairs. http://www.mfa.gov.il/MFA/History/Modern+History/Historic+Events/Elections_in_Isra el_February_2009.htm (accessed May 25, 2009).

Jane's Information Group A. 2008. Israel and Iran: destruction time again?. Jane's Information Group. October 16. http://www4.janes.com.ezproxy.apus.edu/ subscribe/frp/doc_view.jsp?K2DocKey=/content1/janesdata/mags/frp/history/ frp2008/frp70646.htm@ @urrent\&Prod_Name=FREP\&QueryText= (accessed June 16, 2009).

Hughes, Robin. 2006. Israel - protection and survivability: Shield of David. Jane's Information Group. May 16. http://www.janes.com/defence/news/jdw/jdw060518_2_n.shtml (accessed June 16, 2009).

Katz, Yaakov. "Israel foils Hizbullah attack in Europe.” Jerusalem Post. January 28, 2009. http://www.jpost.com /servlet/Satellite?cid=1233050197638\&pagename=JPArticle\%2FShowFull (accessed May 28, 2009).

Kreiger, Hilary Leila and Sabina Amidi. "Mousavi backs away from more rallies." Jpost.com. June 27, 2009. 
http://www.jpost.com/servlet/Satellite?pagename=JPost\%2FJPArticle\%2FShowFull\&cid $=1245924939735$ (accessed June 27, 2009).

Kuperman, Ranan D. Who Should Authorize the IDF to Initiate a Military Operation? A Brief History of an Unresolved Debate. Israel Affairs 11, no. 4: 672-694.

Lebanese Air Force. Aircraft Inventory. Lebanese Air Force. http://www.lebaneseairforce.info/fleet1.htm (accessed June 10, 2009).

Lockwood, Jonathan S. 2008. The Application of LAMP. http://www.lamp-method.org/2.html (accessed May 2, 2009).

Magouirk, Justin. "The Nefarious Helping Hand: Anti-Corruption Campaigns, Social Service Provision, and Terrorism." Terrorism and Political Violence 17, no. 3: 356-375.

Mazzetti, Mark and David E. Sanger. "Obama Expands Missile Strikes Inside Pakistan.” NYTimes.com. February 20, 2009. http://www.nytimes.com/2009/02/21/washington/21 policy.html (accessed June 24, 2009).

Mizroch, Amir. "Ministry: Desalination can't meet water needs." JPost.com. May 14, 2008. http://www.jpost.com/servlet/Satellite cid=1210668628925\&pagename=JPost\%2FJPArti cle\%2FShowFull (accessed June 17, 2009).

Mohamad, Husam. 1998. The PLO's search for a peace strategy. Peace Review 10, no. 2 (June): 173-179.

MSNBC. "Hezbollah chief hails 'divine victory'." MSNBC.com. http://www.msnbc.msn.com/id/14953453/ (accessed June 10, 2009).

Naharnet. "Nasrallah: If We Had Known...We Wouldn’t Have Captured Israeli Soldiers." Naharnet. http://www.naharnet.com/domino/tn/Newsdesk.nsf/Story/208AF7D7155AC5F2C22571 D700634BB0?OpenDocument\&PRINT (accessed June 20, 2009).

Nasr, Vali. 2007. The Shia Revival. New York: W.M. Norton \& Company.

Nissan. "Renault-Nissan and Project Better Place prepare for first mass marketed electric vehicles." Renault-Nissan Better Place. http://www.nissanglobal.com/EN/NEWS/2008/_STORY/080121-02-e.html (accessed June 13, 2009).

Norton, Augustus Richard. 2007. Hezbollah: A Short History. Princeton, NJ: Princeton University Press.

Passner, Deborah. "Hassan Nasrallah: In His Own Words." Committee for Accuracy in Middle East Reporting in America. 
http://www.camera.org/index.asp?x_print=1\&x_context=7\&x_issue $=11 \& \mathrm{x} \_$article $=1158$ (accessed July 18, 2009).

Ranstorp, Magnus. 1997. Hizb'allah in Lebanon: the politics of the western hostage crisis. New York: Palgrave MacMillan.

Rao, Prashant. 2006. Analysis: Hezbollah a force to be reckoned with. Agence France Presse. July 18. http://www.iiss.org/whats-new/iiss-in-the-press/press-coverage-2006/july2006/hezbollah-a-force-to-be-reckoned-with/ (accessed June 16, 2009).

Recovery.gov. "Where is your money going?" Recovery.gov. http://www.recovery.gov/?q=content/investments (accessed June 24, 2009).

Reuters UK. "Israel voices satisfaction over U.S. aid increase." Reuters UK. http://uk.reuters.com/article/idUKL2931674820070729 (accessed June 24, 2009).

Salem, Paul. 2006. The Future of Lebanon. Foreign Affairs 85, no. 6: 13-17.

— 2008. The after-effects of the 2006 Israel-Hezbollah war. Contemporary Arab Affairs 1, no. 1: 15-24.

Sanger, David E. and Mark Mazzetti. "Israel Struck Syrian Nuclear Project, Analysts Say.” NYTimes.com. October 14, 2007. http://www.nytimes.com/2007/10/14/washington/14weapons.html (accessed June 23, 2009).

Siegel, Robert and Ivan Watson. 2006. Lebanon Begins Post-War Recovery Effort. NPR.org. http://www.npr.org/templates/transcript/transcript.php?storyId=5671702 (accessed June 14, 2009).

Spyer, Jonathan. 2008. Lebanon 2006: Unfinished War. Middle East Review of International Affairs 12, no. 1 (March).

http://meria.idc.ac.il/journal/2008/issue1/jv12no1a1.asp (accessed June 9, 2009).

Stratfor. 2006. Israeli Tanks and Hezbollah Countermeasures. Stratfor. http://www.stratfor.com/israeli_tanks_and_hezbollah_countermeasures (accessed June 13, 2009).

Sullivan, Antony T. 2008. War and Rumors of War: The Levantine Tinderbox. Middle East Policy 15, no. 1 (Spring): 125-132.

Time Magazine Department. 2007. Olmert Under Fire. Time Magazine. http://www.time.com/time/magazine/article/0,9171,1617518,00.html (accessed July 2, 2009). 
Trend News. "Those charged with an attempt to Israeli embassy, Gabala radar station in Azerbaijan to have closed trial." Trend News. June 10, 2009. http://newsen.trend.az/azerbaijan/1485862.html (accessed June 10, 2009).

Troy, Gil. "Center Field: Yom Kippur for the Left.” JPost.com. February 11, 2009. http://www.jpost.com/servlet/Satellite?cid=1233304754348\&pagename=JPost\%2FJPArti cle\%2FShowFull (accessed June 14, 2009).

United Nations. 2006. World Population Prospects: The 2006 Revision. United Nations: Department of Economic and Social Affairs - Population Division. No. ESA/P/WP.202.

Wachter, Paul. 2002. "Hezbollah: Lebanon's paper tiger.” Salon.com. http://dir.salon.com/story/news/feature/2002/04/10/lebanon/index.html (accessed June 3, 2009).

YaLibnan. "Jumblatt: Lebanon's Fatah al Islam was made in Syria.” YaLibnan. May 28, 2007. http://yalibnan.com/site/archives/2007/05/jumblatt_lebano_3.php (accessed June 10, 2009). 


\section{Appendix A}

\section{Month Average Retail Price Chart}

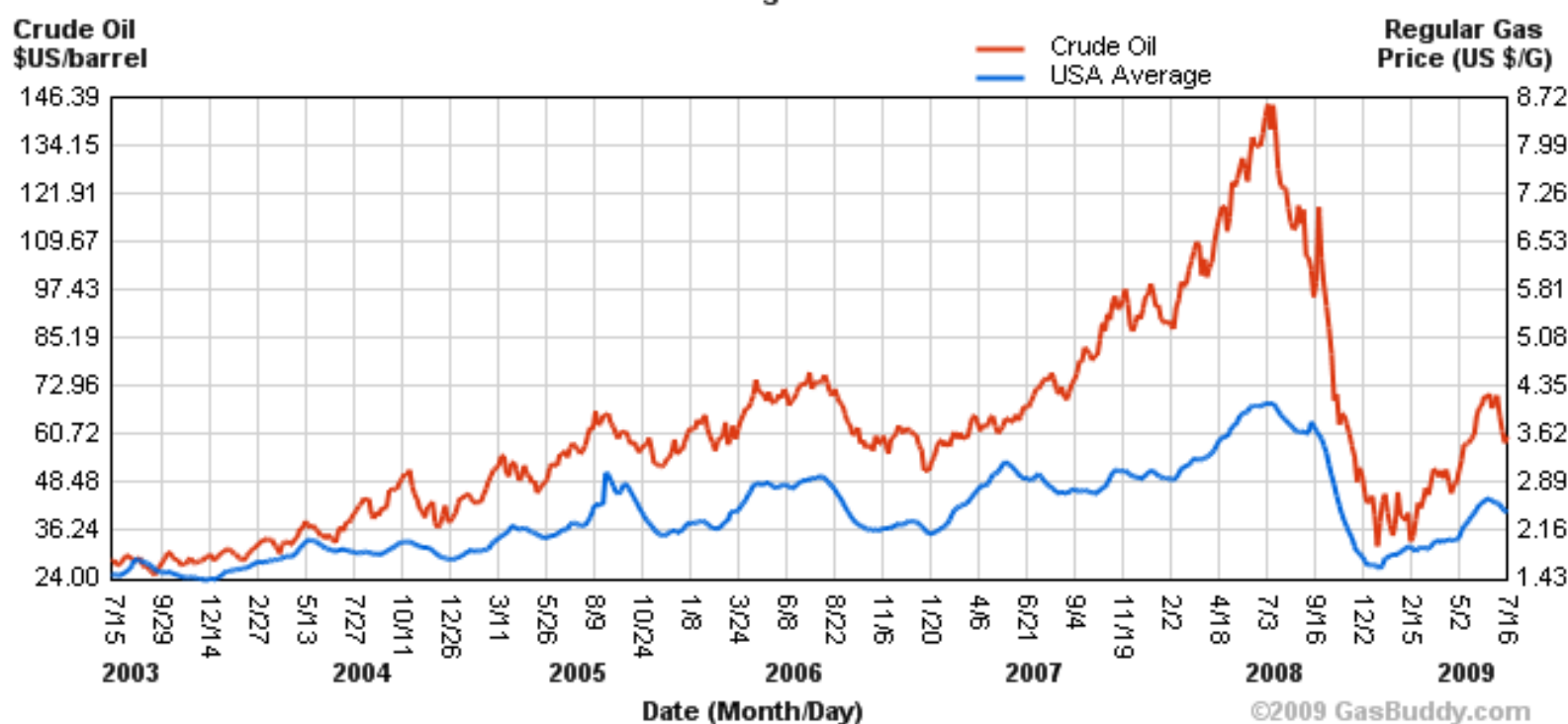

During the 2006 war between Israel and Hezbollah, crude oil prices rose to then-record highs and finally abated in the days following the end of hostilities in August. Average prices for a gallon of unleaded gasoline also reached highs that were just shy of the record high prices set in the aftermath of Hurricane Katrina in 2005. 